\title{
THE IMPACT OF THE INSTITUTIONAL FRAMEWORK QUALITY ON THE OWNERSHIP STRATEGY. EVIDENCE FROM EU FOREIGN DIRECT INVESTMENTS IN SOUTH AND CENTRAL EASTERN EUROPE
}

\author{
Constantinos CHOROMIDES \\ Glasgow Caledonian University, United Kingdom
}

\begin{abstract}
Foreign Direct Investment (FDI) is considered by scholars as a critical factor for economic growth and development. The recent economic crisis in the European Union (EU) has brought up again the discussion of the key drivers specific to the attraction of FDI. In addition to strict economic factor, the literature emphasises the role of institutions in a country as determinants in attracting FDI inflows. This study is one of the first to address the ownership strategy of multinational enterprises from the EU region undertaking FDI in former transitional economies in South (SEE) and Central Eastern Europe (CEE) using the concept of the quality of institutions. An analysis of the impact that the quality of market supporting institutions in determining ownership structure has of foreign affiliates in former transitional economies is attempted using an econometric model on institutional, regulatory, country specific and company level data based on a sample of $285 \mathrm{EU}$ companies undertook FDI in 4 South and Central Eastern European countries during 19952015. We apply and advance the institution-based view of strategy by integrating it with resource-based and transaction cost considerations, incorporating three of the most important theoretical paradigms of international business studies.
\end{abstract}

Key Words: Foreign Direct Investment, South and Central Eastern Europe, institutional variables, institutional distance, ownership strategy, decision making.

\section{Introduction}

International business (IB) is subject to higher transaction costs than most domestic business, due to imperfections on international markets making the choice of an organisational form a key issue in IB strategy (Williamson 1985, 2000, Teece 1986, North 1990). The choice of entry mode, the most critical strategic decisions for the companies entering foreign markets, has been addressed frequently in the literature (Kim and Hwang 1992, Arregle et al. 2006, Brouthers and Hennart 2007, Kaynak et al. 2007). Most of the studies focused on the choice of ownership between a joint venture (JV) and a wholly owned subsidiary (WOS) (Brouthers and Brouthers 2003, Brouthers and Hennart 2007, Dikova and van Witteloostuijn 2007, Yu et al. 2015) and on the management of JV and WOS (Meyer 2002, Meyer and Tran 2006, Bertoncelj et al. 2007).

Each host country represents a unique institutional environment which has a significant impact on companies' ownership strategy (Henisz 2003, Dunning 2004, Dunning and Lundan 2008, Estrin et al. 2009). Previous research has also focused on the importance of understanding the institutional environment to gain a comprehensive understanding of market entry strategy issues in transitional economies where institutional frameworks differ greatly from those in developed economies (Brunetti et al. 1997, Stiglitz 1999, Svejnar 2002, Meyer and Peng 2005, Wright et al. 2005, Gelbuda et al. 2008). Therefore, an increasing number of studies are using different institutional perspectives to examine the entry mode and preferred ownership strategies in their foreign markets (Hennart 1988, Xu et al. 2004, Wright et al. 2005, Estrin et al. 
2009, Meyer et al. 2009a, Peng and Khoury 2009). There are reasons to believe that a sound institutional environment should attract more FDI. Nonetheless, according to the literature (Lim 2001, Blonigen 2005, Mccloud and Kumbhakar 2012), evidence in favour of institutions remains mixed. The lack of conclusive evidence has been attributed to measurement, conceptual, and methodical problems.

Three factors have contributed to the growing interest in the relationship between FDI and institutions. First, the influential study of North (1990) raised awareness on the role of institutions in establishing incentives for the economic activity in general and for investment in particular. An early attempt to study this issue is Wheeler and Mody (1992), who use the first principal component of 13 risk factors (including bureaucracy, political instability, corruption and the legal system quality). However, they did not find a significant impact of 'good' institutions on the location of US foreign affiliates. Second, FDI flows grew significantly since the 1990s and emerging market economies have become increasingly interested in attracting a greater share. Third, foreign investors have come to place a greater emphasis on institutional quality when selecting an investment location (Bevan et al. 2004, Acemoglu et al. 2005).

This study concentrates on FDI made in SEE and CEE economies as they pose particular challenges to investors because multiple market failures, such as the unregulated markets, the incapacity of commercial infrastructure, the absence of the legal framework protecting the interests of the shareholders and the proprietary assets of companies during the transition process have to be accommodated and it is not feasible to work with the efficient- market assumptions suitable for developed economies. Thus they offer a novel context for the understanding of different international management issues. These countries have a unique history in relation to the transition to a market economy system from socialism and the development of economic institutions (Meyer 2001a, Svenjar 2002, Meyer and Peng 2005, Arslan and Larimo 2010).

Previous research on developing, developed, emerging and transition economies has described different ways in which institutions affect FDI (Addison and Heshmati 2003, Edison 2003, Bevan and Estrin 2004, Pournarakis and Varsakelis 2004, Rodrik 2004, Rodrik et al. 2004, Acemoglu and Johnson 2005, Aizenman and Spiegel 2006, Bénassy-Quéré et al. 2007, Naudé and Krugell 2007, Becchetti and Hasan 2008, Dumludag 2009, Ali et al. 2010, Buchanan et al. 2012, Farole and Winkler 2012). The dominant view is that countries with good institutional governance can attract more FDI (La Porta et al. 1997, 1999, Globerman and Shapiro 2002, Kaufmann et al. 2005, Globerman et al. 2006, Busse and Hefeker 2007, Gani 2007, Buchanan et al. 2012), whereas an environment of weak governance cannot protect the investments (Globerman and Shapiro 2003). Institutional variables, specifically corruption, political restrictions, and protection of property rights, are some important determinants of multinational investments and FDI inflows (Contractor and Lorange 1988, Shleifer and Vishny 1993, Mauro 1995, Singh and Jun 1995, Henisz 1998, Wei 2000, Jensen 2003, Richards and Nwankwo 2005, Gorynia et al. 2015). Staats and Biglaiser (2012) argue that rule of law and judicial strength are important determinants of FDI inflows.

Further, some scholars argue that in countries where property rights are poorly protected, multinationals' investments face expropriation risks (Henisz and Williamson 1999, Henisz 2000a). Jimenez (2010) argues that multinationals implement their internationalisation policies by investing in countries where political risk levels are very different, aiming to achieve maximum benefit by acquiring the knowledge and access to managerial talent, as well as diversifying their FDI portfolios, to minimise risk against local fluctuations in supply and demand; thus positional advantages can be achieved by investing in countries where political capabilities can be used to gain economic benefits and healthy effects. Greater assurances to comply with contracts, respect for property rights, and economic freedom are important determinants to attract more foreign investment (Stephen and Philip 1995, Kapuria-Foreman 
The Impact of the Institutional Framework Quality on the Ownership Strategy. Evidence from EU Foreign Direct Investments in South and Central Eastern Europe

2007).

Dunning (1995) introduced an eclectic paradigm, known as the OLI paradigm, with three important elements needed in order to motivate investment in a particular country: ownership, location and internalisation advantages. Dunning's location advantages include: supply side (labour skills and costs, corporate taxation), demand side (market size and growth), and political and social infrastructure. Since Dunning's initial paradigm did not specifically include institutional factors, being principally focused on economic factors, Dunning (2006) emphasized the importance of institutional factors in an extension of the model. It has also been suggested that institutions affect all three components of the paradigm (Dunning and Lundan 2008).

Ali et al. (2010) concluded that property rights were more important determinants of FDI. Law and order become a serious issue for foreign investors when courts fail to enforce contracts and when the government influences court decisions for political motives (Drabek and Payne 2002, Buchanan and English II 2007). Law and order instability leads to corruption (Dahlström and Johnson 2007). Many investor surveys also suggest that one of the most important institutional factors that deters FDI inflows is corruption (Gastanaga et al. 1998, Campos et al. 1999, Asiedu and Villamil 2000, Wei 2000, Egger and Winner 2005, Cuervo-Cazurra 2006, 2008). Nevertheless, this result was challenged by Stein and Daude (2001) who argued that high correlation between corruption and GDP per capita could lead to spurious results as GDP per capita was not included in the equation.

On the other hand, institutional quality is associated with economic growth (North 1981, 1990, 2005, Butkiewicz and Yanikkaya 2006). Previous research studies on the important determinants of FDI in developing countries have argued that institutional quality is the most important factor in stimulating economic growth. North (1990) explains that institutions are formulated to reduce the uncertainty associated with human exchange and provide societies with a predictable framework for interaction. Globerman and Shapiro (2002) found that the returns for good governance are strong for developing economies, relative to other countries in their sample.

The view that economic problems in developing countries arise due to the poor quality of institutions is very common among researchers and policymakers; lower institutional quality is associated with lower investment, low productivity growth, low per capita income, and overall slower output growth (Akhter 1993, , Globerman and Shapiro 2002, Jude and Levieuge 2017). Good institutions reduce production and transaction costs (North 1990,1991), and as a result, increase profitability and economic activity, whereas poor and weak institutions increase uncertainty and costs of production (Cuervo-Cazurra 2006, 2008). North (1990) illustrates that parties at the opposite ends of an economic activity have incomplete information about their counterparts' true intentions; who might cheat or deceive others. Due to the lack of information and uncertainty associated with economic transactions, transaction costs contain a risk premium. North (1990) argues that the risk premium is a function of institutional quality, as it depends upon property right protection, contract enforceability, and the likelihood of default by the other party.

In general, it is accepted that countries that record higher economic prosperity have greater political and economic freedom, better rights protection and intellectual property rights and lower level of corruption, thus perform relatively better in terms of FDI inflow (Acemoglu et al. 2005, Bénassy-Quéré et al. 2007). Buchanan et al. (2012) pointed out that the quality of institutions not only relates to the amount of FDI but also with their variability. Wheeler and Mody (1992), Gani (2007), Groh and Wich (2009), suggest that complex and time consuming bureaucratic procedures affect the expected returns from investments, thereby negatively affect the decisions of foreign investors. Khan and Akbar (2013) employed several political risk indices such as government stability and corruption, while other studies have used corruption 
as a measure of political risk displaying a negative impact on FDI (Wheeler and Mody 1992, Wei 2000, Wei and Shleifer 2000, Getz and Volkema 2001, Habib and Zurawicki 2002, Bénassy-Quéré et al. 2007). Similar factors were also indicated by Wheeler and Mody (1992), and Filippaios and Kottaridi (2013), who emphasize the particular influence exerted by corruption. Finally, Bénassy-Quéré et al. (2007) find the impact of financial efficiency, the stability of the tax system, and the efficiency of the judiciary and of supervisory instruments to be among those factors which exercise significant influence on FDI.

The impact of 'institutional distance' between the home country and the host country was recently scrutinised by Bénassy-Quéré et. al. (2007). The analysis provides robust evidence that institutions do matter independently of the countries' development level. In fact, the results show that inward FDI is positively affected by public efficiency, which includes tax system, transparency and lack of corruption, property rights and the facility to create a business.

In sum, many empirical studies stress the relevance of institutional variables supporting the idea that an efficient legal framework reduces economic uncertainties. So, most of them sustain that the existence of clear and enforceable laws to ensure property rights, low corruption and bureaucracy levels, effective tax system and macroeconomic and political stability influences positively the FDI flows and economic growth. If these conditions do not exist in host countries, foreign investors can face particularly high costs in establishing their investments (Wei and Shleifer 2000, Globerman and Shapiro 2002, 2003, Stern 2003, Blonigen 2005, Globerman et al. 2006, Busse and Hefeker 2007, Daude and Stein 2007, Gani 2007, Busse and Groizard 2008, Pantelidis and Nikolopoulos 2008, Bitzenis et al. 2009, Dutta and Roy 2009, Barthel et al. 2010, Bussmann 2010, Berger et al. 2011, 2013). Host countries with a sound business environment are able to attract more FDI (Dutta and Roy 2009) and reap the benefit of FDI and achieve economic growth more effectively (Busse and Groizard 2008, Baek and Qian 2011).

The motivation for studying the importance of the quality of institutions and the effectiveness of regulations as determinants on ownership strategy in SEE and CEE markets is that only recently these factors have been studied as determinants of FDI in former transitional economies (Meyer et al. 2009b, Arslan and Larimo 2010, Kaditi 2013, Estrin and Uvalic 2014, Choromides 2015). Thus, the objective of our study is to provide a theoretical framework and empirical evidence as to whether and to what extent the quality of institutions and regulations have an impact on the ownership strategy of FDI made by companies in these markets. For the purpose of this research, the SEE region consists of Bulgaria and Romania, and the CEE region consists of Hungary and Poland.

Our study is one of the first of its type to address the regulative institutional distance specifically and their impacts on ownership strategies of companies from the EU region in these markets. Because significant FDI into these two regions is occurring for the first time, much can be learned from the experience of foreign companies, as this is presented in this study. The opening of these markets provided opportunities for studying the conditions influencing the strategic aspects of internationalisation in transitional economies.

The paper is organised as follows. The first session presents an overview of the evolution of FDI and institutional quality in SEE and CEE, followed by the discussion about the theoretical background leading to the development study hypotheses. In section three, the econometric model is explained, along with the dependent as well as the explanatory variables, the data collection procedure, whereas the empirical results are presented in the fourth section; section five concludes with providing conclusions, limitations, and future research directions. 
The Impact of the Institutional Framework Quality on the Ownership Strategy. Evidence from EU Foreign Direct Investments in South and Central Eastern Europe

FDI and institutional development in SEE and CEE

In the attempt to set up market economies for the former transitional economies and being new members of the EU, much attention was devoted to measures such as macro-stabilisation, inflation, privatisation, price and trade liberalisation (Apergis and Katrakilidis 1998, Gligorov 2000, Hunya 2000, Ramcharran 2000, Petrakos and Totev 2001, Kogut and Spicer 2002). Research in these fields is necessary in order to understand the structural changes; however, the lack of research in the role of institutions as determinants in attracting FDI reflects a more general neglect of these economies. More research is needed to understand the investment modes connected with the investment motivations (Wach and Wojciechowski 2016). The strategic location of the two regions in the European continent, the opening of local markets for trade and investment, the continuous efforts in promoting institutional reforms for deeper integration in the EU, the comparatively low level of labour costs are only but a few of the determinant facts that make the two regions attractive for international investors. This is evidenced by the acceleration of FDI as illustrated in Fig. 1. However, companies operating in the region faced a distinct institutional framework, which predetermined the strategic opportunities for businesses, thus creating challenges for foreign companies. After years of growth, all regional economies experienced a deep recession as a result of the global financial crisis in 2008, with a more profound evidence in Bulgaria and Romania (Choromides 2015).

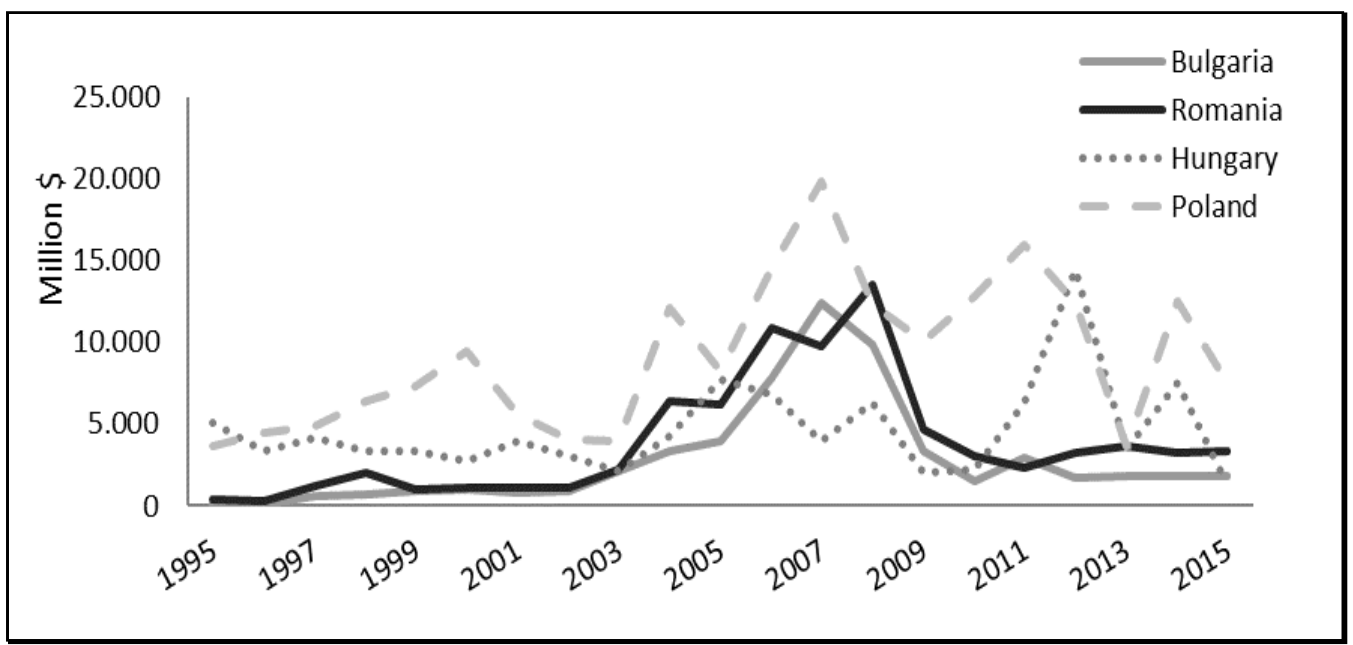

Fig. 1 - FDI inflows in SEE and CEE regions (1995-2015)

Source: UNCTAD statistics (processed by the author

Bulgaria's score is 67.9, making its economy the 47th freest in the world and 23rd in the region in the 2017 Index. Since 1995, Bulgaria's economic freedom has increased by 16.8 points, with gains recorded in nine of the ten categories, led by the management of government spending, tax burden and monetary freedom. Bulgaria's transition to a more open economy and flexible economic system has been facilitated by substantial restructuring. Competitive flat tax rates and an open trade regime, supported by a relatively efficient regulatory framework, have encouraged development of a growing private sector. The financial sector demonstrated a relatively high level of resilience during the 2014 liquidity crisis. The management of public finance has been relatively sound. The level of public debt continues to be among the lowest in the region, with budget deficits declining. Yet, deeper and more committed institutional reforms are needed in areas like judicial effectiveness and government integrity to help ensure longterm economic development (Chadee et al. 2014, Heritage Foundation 2017a). 
Romania's score is 69.7, making its economy the 39th freest in the world and 20th in the region in the 2017 Index. Romania continues to recover from the recent global economic slowdown and it has made fiscal sustainability a priority. Economic growth rates have improved, but the benefits have not been felt by all Romanians. The country continues to have the highest poverty rate in the EU. Progress on implementing reforms and improving the business environment has been uneven. Since 1995, Romania's economic freedom has increased by 23.1 points, with gains recorded in nine of the ten categories, reflecting significant improvements in all indicators except financial freedom. Yet, the unpredictable and uneven regulatory system discourages investors from doing business. Efforts to privatise state owned enterprises have stalled in the past two years. Corruption is endemic at all levels of governments and it undermines the rule of law. Despite, the remarkable economic performance in the recent years and its accession in the EU in 2007, progression in terms of judicial independence and anti-corruption processes remain inefficient (Chadee et al. 2014, Heritage Foundation 2017a).

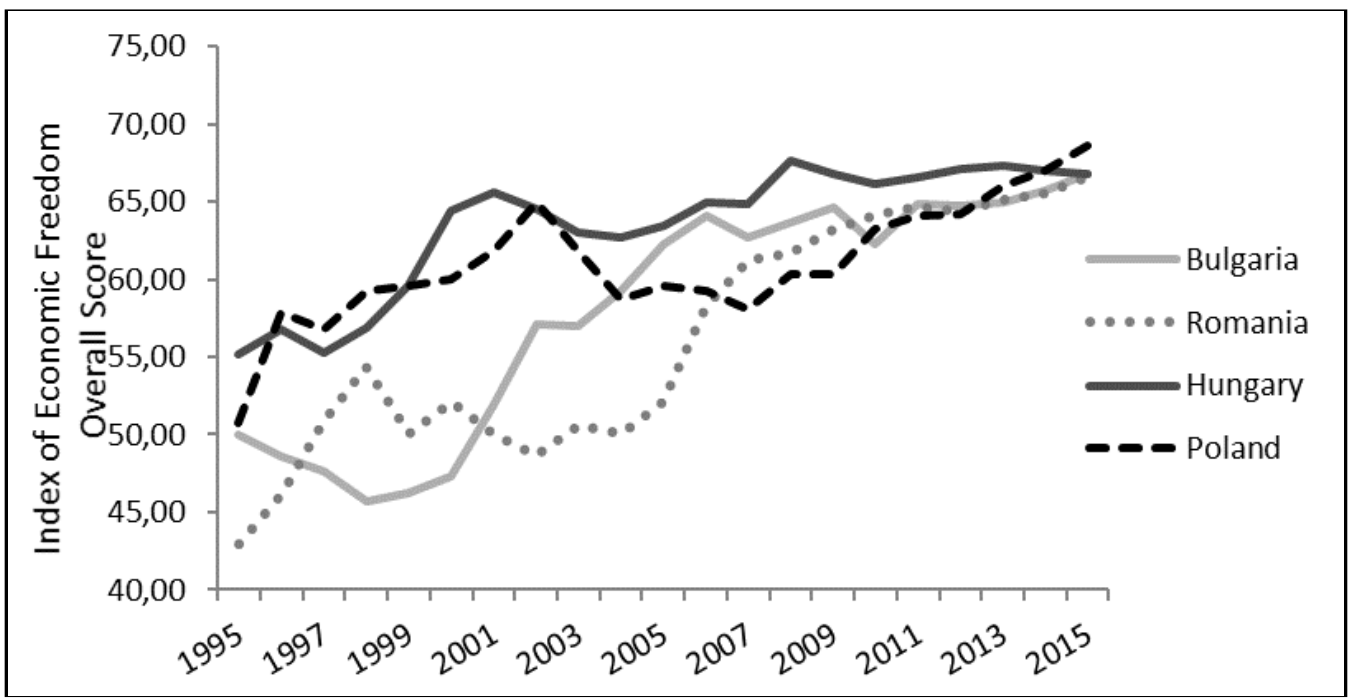

Fig. 2 - Index of Economic Freedom (1995-2015)

Source: Heritage Foundation 2017a (processed by the author)

Poland's score is 68.3 , making its economy the 45th freest in the world and 21 st in the region in the 2017 Index. Since 1995, Poland's economic freedom has increased by 17.9 points. Gains were recorded in eight of the ten categories, led by tax burden, government spending, monetary freedom, labour and trade freedom. The economy has demonstrated a high degree of macroeconomic resilience. Structural reforms that have included trade liberalization, implementation of a competitively corporate tax rate, and modernisation of the regulatory environment have facilitated the transition to a market-oriented economy but further reform is necessary if Poland is to achieve a broad-based economic freedom and growth. Indeed, institutional reforms must support judicial independence and effectiveness and tackle corruption in order to strengthen the foundations of economic freedom and to ensure progress toward greater economic dynamisms and prosperity. Fiscal consolidation and prudent management of public finance are ongoing concerns. The government needs to reduce the budget deficit and to curb the growth of public debt (Chadee et al. 2014, Heritage Foundation 2017a). 
Hungary's score is 65.8 , making its economy the 56th freest in the word and the 27th in the region in the 2017 Index. Hungary has implemented critical reforms in many areas. Since 1995, Hungary's economic freedom has increased by 11.6 points. Gains were recorded in six of the ten categories, led by tax burden, government spending, monetary freedom, financial freedom, labour and trade freedom. Licensing procedures have been streamlined, and the overall entrepreneurial environment is further aided by strong trade freedom, business freedom, and investment freedom. The economy has grown at a robust pace over the past few years and it has now significant momentum. Consolidating public finances and further encouraging economic growth remain policy priorities. Additional fiscal adjustments are needed to put public debt on a firmly downward path and provide more space for vibrant private sector activity (Chadee et al. 2014, Heritage Foundation 2017a).

\section{Theory and Hypotheses Development}

Companies face two strategic choices when they enter new markets using FDI as an entry strategy (Dikova and van Witteloostuijn 2007, Slangen and Hennart 2008). The first choice is referred to as establishment mode choice, where companies either opt to set up their subsidiaries from scratch or acquire an on-going concern (Brouthers and Brouthers 2000, Slangen and Hennart 2008). The second choice is referred to as ownership mode choice in the literature, where the companies decide whether they intend to establish their operation alone or jointly manage the affiliates with local partner(s) (Chen and Hennart 2002, Brouthers and Hennart 2007, Arslan and Larimo 2010). It is important to understand the impacts of the main determinants on ownership mode choice. A review of studies on ownership mode choice of companies reveals that transaction cost economics (TCE) has been used as the theoretical basis for the analysis of its determinants in many cases (Brouthers 2002, Demirbag et al. 2007, Morschett et al. 2010). TCE proposes both host country and home country related determinants that influence the benefits and costs associated with choice between WOS or JV. Scholars have also used the resource based view (RBV) (Chen and Hennart 2002, Herrmann and Datta 2002, Claver and Quer 2005) and institutional theory (IT) (Dikova and van Witteloostuijn 2007, Arslan and Larimo 2010, Arslan 2011) as theoretical bases for the analysis of ownership mode choices of investing companies in their international markets.

It is evident that IB research as a research area is multidisciplinary in nature, and international business decisions and strategies have been analysed in many cases by using multiple theoretical frameworks (Meyer and Peng 2005, Brouthers and Hennart 2007). Due to the specific nature of CEE and SEE, there is a need to adopt a more comprehensive theoretical approach by integrating arguments from all the afore-mentioned theories. So far, no previous study concentrating on CEE and SEE regions (at least to our knowledge) has comparatively analysed the determinants of ownership mode choice based on these three theoretical bases. Therefore, the main goal of our paper is to analyse the impacts of important determinants of ownership mode choices of companies by incorporating a range of ownership mode choice determinants found significant in past market entry mode analysis studies (Brouthers and Hennart 2007, Dikova and van Witteloostuijn 2007, Arslan and Larimo 2010). Our analysis will be based on the assumption that companies aim at maximising their expected rate of return from operating abroad, which, in turn, implies minimising the risk and the cost of establishing their production units abroad. The viewpoint adopted in this section is that entry mode choices are most usefully and tractably viewed as a trade-off between control and the cost of resource commitments, often under conditions of considerable risk and uncertainty (Vernon 1983, Root 1987, Hill et al. 1990).

JV and WOS are used to access resources previously embedded in another organisation. Yet, why would investors not rather buy the specific resources they need using standard market transactions? Acquiring a company exposes a company to major challenges in managing the purchased business (Capron et al. 2001), and a JV creates substantial coordination challenges 
(Buckley and Casson 1998). Thus, if the local markets for the necessary resources are efficient, entrants may buy the required resources using market transactions. However, the efficiency of local markets is not always the norm. Markets for acquisitions may be especially problematic in the emerging economies, since the markets for acquiring local resources may be suboptimal because of the institutional environment governing the transaction or they may also be suboptimal because of the characteristics of the sought resources (Peng and Heath 1996, Meyer and Estrin 2001, Estrin 2002, Peng 2006).

IT has been used to assess different aspects of the market entry mode strategies (Eden and Miller 2004, Xu et al. 2004, Gaur and Lu 2007), suggesting that the institutions and the differences between home and host country institutions impact different aspects of the ownership strategies of the companies (Gaur and Lu 2007, Estrin et al. 2009, Chao and Kumar 2010). Other studies addressed the transfer and the adoption of organisational practices and strategies in subsidiaries and the impact of different institutional factors on them (Guler et al. 2002, Kostova and Roth 2002, Brouthers and Brouthers 2003, Gaur and Lu 2007). Therefore, we aim to concentrate on institutional distance in our study to analyse its impacts on ownership strategy so as to contribute to this emerging area of interest from a European company perspective. Institutions have an essential role in supporting the effective functioning of the market mechanism, such that companies and individuals can engage in market transactions without incurring undue costs or risks (Peng 2008). These institutions include, for example, the legal framework and its enforcement, property rights, and regulatory regimes (Busse and Hefeker 2007, Busse and Groizard 2008, Dutta and Roy 2009, Barthel et al. 2010, Berger et al. 2011, 2013). We consider institutional arrangements to be 'strong' if they support the voluntary exchange underpinning an effective market mechanism. Conversely, we refer to institutions as 'weak' if they fail to ensure effective markets or even undermine markets.

Institutional differences are particularly significant for companies operating in multiple institutional contexts (Meyer and Tran 2006). Formal rules establish the permissible range of entry choices but informal rules may also affect entry decisions. Thus, legal restrictions may limit the equity stake that foreign investors are allowed to hold and informal norms, such as norms concerning whether bribery is acceptable, may favour locally owned companies over MNEs. In other words, because the transactions costs of engaging in these markets are relatively higher, MNEs have to devise strategies to overcome these constraints (Peng 2003, 2008). Institutions also provide information about business partners and their likely behaviour, which reduces information asymmetries - a core source of market failure. In many emerging economies, weak institutional arrangements may magnify information asymmetries so companies face higher partner-related risks and need to spend more resources searching for information (Meyer 2001a, Tong et al. 2008). The strengthening of the institutional framework thus lowers the costs of doing business (Estrin 2002, Bengoa and Sanchez-Robles 2003, Bevan et al. 2004) and it influences foreign entrants' decisions by moderating the costs of alternative organisational forms. In consequence, the relative costs associated with different entry modes are affected by the institutional framework (Henisz 2000b, Meyer 2001b).

In particular, JV provides a means to access resources held by the local companies. However, the need for a partner may decline with the strengthening of the institutional framework (Meyer 2001b, Peng 2003, Steensma et al. 2005). For example, as the regulatory environment in an emerging economy improves, more sectors will be opened to FDI and foreign entrants will face fewer formalities, permits, and licenses. Hence, a reduction of restrictions on FDI may reduce the need for a local JV partner as an interface with local author ties (Peng 2006). Similarly, improved regulatory frameworks may reduce the need to rely on relationships of a local partner when dealing with local businesses (Meyer 2001a). Entry by acquisition is particularly sensitive to the efficiency of markets, especially financial markets and the market for corporate control (Peng 2008). Transactions in financial markets are greatly facilitated by an institutional framework that ensures transparency and contract enforcement (Beim and Calomiris 2003). 
However, institutional arrangements and the efficiency of financial markets vary considerably between the developed and the emerging economies (Kedia et al. 2006, Young et al. 2008, Lin et al. 2009). In addition, weak institutions lead to a lack of transparent financial data and other information on companies and a shortage of specialised financial intermediaries (Khanna et al. 2005). Many of the resources and organizational structures of local companies are built around nonmarket forms of transactions, and they are therefore harder for potential acquirers to evaluate (Tong et al. 2008). This raises the complexity and transaction costs of undertaking the due diligence and contract negotiations necessary for acquisitions and post-acquisition restructuring (Peng 2006). Thus, costs and risks increase when institutional frameworks are weaker. Combining these arguments, we posit that foreign entrants may need access to local resources in emerging economies to overcome inefficiencies caused by weak institutions. Yet, at the same time, weak institutional frameworks make it more difficult to access these resources via market transactions and they raise the costs of acquiring local companies. In contrast, JV provide a means to access local resources where arm's-length market transactions are difficult.

Economic freedom distance between home and host countries of a company can be a source of uncertainty for the investing company in a new environment (Demirbag et al. 2010) and it can lead to additional costs for the investing company's operations in that particular market. These costs result from unfamiliarity hazards as referred to in some earlier studies (Gaur and Lu 2007, Demirbag et al. 2010). Unfamiliarity hazards emerge from the investing companies' lack of knowledge about the host country institutions (Demirbag et al. 2010) and they are also a major hurdle in managing a subsidiary (Delios and Henisz 2003, Gaur and Lu 2007). The weakness of market economy institutions in any country has been mentioned as a major source of these problems for the investing companies (Meyer et al. 2009a, Demirbag et al. 2010). The weakness of market economy institutions in the host countries is also evidenced by the presence of a low level of economic freedom there (Gwartney et al. 2008). Economic freedom distance can be referred to as a manifestation of the differences in terms of strength of the market economy institutions between the home and the host countries of MNEs (Demirbag et al. 2010). As referred earlier, the ownership mode represents the important market entry mode strategies of companies and the difference in the levels of economic freedom between the home and the host country is expected to affect them significantly.

The regulative institutional distance refers to the differences in the legal institutions and the prevalent laws in a company's home country and the host country (Xu and Shenkar 2002, Xu et al. 2004). These existing laws can promote certain types of business behaviours and restrict others (Scott 2008). Therefore, these regulative institutions can influence the strategies of companies because of the risks and penalties associated with the organisational deviance from legal rules (Henisz 2005). Moreover, the host country government can use its authoritative and regulative powers to restrict or influence the behaviour of enterprises (Grewal and Dharwadkar 2002). Previous studies have also shown that the legal restrictions on foreign owned companies tend to discourage the formation of WOS (Eden and Miller 2004, Gaur and Lu 2007, Scott 2008). Further on, the regulative institutions establish a stable structure consisting of the rules to reduce uncertainty and transaction hazards for companies (Meyer 2001a, Meyer and Peng 2005).

IT proposes that FDI choices and decisions of internationalising companies are considerably influenced by the effectiveness of market economy institutions of their target countries (Child and Tsai 2005, Meyer and Peng 2005). The quality of market institutions and the resulting strength of market conforming values in the target country are important determinants of the company's foreign market entry decisions including FDI ownership mode choices (Arslan 2011). With respect to FDI ownership mode choices, restriction on ownership and entry mode options by target governments due to developing market economy institutions (Khanna and 
Palepu 2010) is a major concern for the investing foreign companies (Trevino et al. 2008). On the other hand, the results by Child and Tsai (2005) indicate that when companies operate in favourable external circumstances, they tend to commit more resources to the target country e.g. formation of WOS. Some studies have also mentioned that lesser restrictions on ownership options can motivate companies to prefer WOS over JV (Chung and Beamish 2005). Finally, Li et al. (2007) also found that if market conforming values in the target country are strong, then the institutions become less restrictive and WOS become more acceptable in the target country. Consequently, in a target economy with strong market conforming values, acquisitions of local companies can be a preferred strategy of companies (Arslan 2011).

Hypothesis 1: Strong market conforming values in the target country are positively associated with the propensity of firms to choose WOS over JV.

International experience has been referred to as an important factor in the entry mode choice (Brouthers and Brouthers 2000, Brouthers and Hennart 2007). The familiarity with the international markets can reduce companies' uncertainty (Barkema et al. 1996, Meyer and Tran 2006) due to accumulated knowledge of foreign operations, which in turn influences the ownership strategy. As companies accumulate more experience in international markets, they develop efficient processes and systems for managing their global operations (Anderson and Gatignon 1986). Ellis (2008) refers that the international experience of the company can diminish the influences of psychic distance. The same can be also said about institutional distance. This is because companies with operations in multiple markets develop a structural ability to adapt (Tallman and Fladmoe-Lindquist 2002); thus, when they encounter relatively unfamiliar territory, their adaptation is rather fast. Moreover, international experience may reduce the risks and uncertainties perceived during the international expansion because companies have learned how to manage new foreign entries from their previous experiences (Caves and Mehra 1986).

Familiarity of companies with the local context may offset some of the barriers of regulative and normative distance (Gaur and Lu 2007). The international experience can help companies by providing similarity of the context and commercial experience in the country; companies develop familiarity with local environments through a process of acculturation that reduces the effects of distance (Shenkar 2001, Tang and Devinney 2015). Tallman and Fladmoe-Lindquist (2002) and Clarke et al. (2013) argued that companies with more extensive international experience may leverage more easily their resource-based or knowledge-based capabilities to further their internationalisation. It has also been referred that companies gain institutional knowledge about the host country during the process of internationalisation. Therefore, international experience has been found to reduce the "liability of foreignness" (Zaheer 1995) and the problems with understanding the laws and norms that apply in a foreign context (Zekiri 2016). Henisz (2003) argued that the ability to manage institutional idiosyncrasies is a specialised skill that requires experience over time and across countries for the companies. Hence, internationally experienced companies are more likely to replicate their home activities in the host country based on their strategic goals. Therefore, internationally experienced companies are expected to form WOS in their new international markets (Dikova and van Witteloostuijn 2007, Ellis 2008).

Hypothesis 2: The more experienced in foreign markets a company is, the greater the probability of observing fully owned affiliates.

To understand the contribution of the RBV in the framework it is necessary to review the factors that influence mode choice. Resources can be obtained in bundled form by taking over an existing local company or they can be redeployed within the company to establish a new venture, or invest together with a local company. The ownership choice depends first on the resources needed, behind which lie the strategic objectives of the project, and, second, on the 
resources that are found (i) within the entering foreign company, and (ii) in bundled form in local companies. Since a major motive underlying FDI in SEE and CEE appears to be resource seeking, we explore the possibility of labour costs affecting the companies' choice regarding the affiliate ownership structure. Transaction cost considerations may lead the companies to share in order to gain access to skilled labour (Kaynak et al. 2007, Ra and Abuova 2017). On the other hand, given that it is unreasonable for companies to pay relatively high wages for nothing, the rationale behind a possible labour cost effect is that industries may experience high unit labour costs due to a skilled and highly qualified workforce. Companies operating in those industries may possess an intangible asset-workforce's capabilities, which is likely to yield large profits. Therefore, we explore whether high unit labour costs tend to lead to high foreign ownership share.

Hypothesis 3: The more labour intensive a company is, the greater the probability of observing fully owned affiliates.

In emerging economies, investing companies usually require context-specific resources to achieve competitive advantages (Meyer and Peng 2005). In contrast, the strategic management literature on entry strategies has primarily focused on the characteristics of resources to be transferred (Brouthers et al. 2008a, Cui et al. 2014) and the characteristics of the investing company (Resmini 2000, Wei et al. 2005, Meyer et al. 2009a). This suggests a need to complement this literature by considering the characteristics of these sought resources. Foreign entrants that consider local resources to be important for their competitiveness may prefer to establish their operation with a local partner as a JV as opposed to WOS. It seems plausible that access to the best resources is already in the hands of local companies, and that the best way to access these resources is to invest in the local company that holds them. Production processes specialised in the use of a particular input quality may be dependent on one source for their raw material. Such dependence arises particularly in industries processing natural resources (Faeth 2009). Resource orientated companies may not find a way to efficiently contract out the required resources and set up fully WOS thus use the JV channel to gain access to them (Helfat and Peteraf 2003).

Hypothesis 4: The more resource intensive a company is, the more likely is to choose shared ownership.

Transaction costs are determined by several factors. One of them is the capital cost of establishing a physical presence overseas (Zhao et al. 2004, Brouthers and Hennart 2007). Higher level of capital intensity of a foreign expansion demands greater resource commitment, but it may yield large profits. Such a commitment not only strains a company's capital and human resources but it also increases business and political risk (Noorbakhsh et al. 2001, Sels 2006). Although high profits may induce companies not to share ownership with local partners, high capital requirement may lead them to share potential financial risks by engaging in a partial ownership structure, thereby diminishing its resource constraint (Dunning 1995). The higher costs suggest that as the investment size increases, multinationals are more likely to choose shared control mode such as JV. Gatignon and Anderson (1988) and Erramilli and Rao (1993) find evidence supporting the reverse relationship between capital intensity and high control mode.

Hypothesis 5: The higher the capital intensity of a company is, the greater the probability of sharing ownership.

Companies with a high level of R\&D intensity are likely to transfer a significant amount of knowledge to their subsidiaries. These companies are expected to face great difficulties in pricing the technology and enforcing the contracts with JV partners (Anderson and Gatignon 1986, Hennart 1991). Consequently, companies spending more on R\&D prefer to choose WOS 
in order to completely control their proprietary know-how and/or best exploit such know-how in their international markets (Deng 2009, Meyer et al. 2009b). Results in several previous empirical studies (Padmanabhan and Cho 1996, Cho and Padmanabhan 2005, Chiao et al. 2010, Lee 2010) have supported the view that high R\&D intensity tends to increase the probability of companies to choose WOS rather than JV, however in CEE specific studies, the empirical results regarding the impacts of $R \& D$ intensity on the ownership mode choice have been mixed. Brouthers (2002), Dikova and van Witteloostuijn (2007), and Paul and Wooster (2008) found a non-significant impact of R\&D intensity on the ownership mode choice whereas results by Brouthers et al. $(2003,2008 b)$ discovered a positive relationship between the R\&D intensity and the higher degree of ownership.

Technology intensive companies face information asymmetries in the transfer of production technology, in uncertain assessment of market opportunities for innovative products, in the necessary feedback from sales to product development, in the training-needs of sales and service personnel (Caves 1996), as well as the free-rider potential for users of brand names who may degrade the quality of products (Anderson and Gatignon 1986). Product sensitivity also increases with the transfer of product innovations, which are more difficult to evaluate than process innovations (Brada 1981) and with the transfer of unstructured, poorlyunderstood products and processes (Anderson and Gatignon 1986).

Kogut and Zander (1995) differentiated between JV and WOS in their study of the impact of knowledge transfer on mode choice. Noting that knowledge-transfer is most efficient in WOS, they showed that the more tacit, less teachable and more complex company specific knowledge is, the more likely it will be transferred via a WOS. This suggests that companies with greater reliance on difficult to transfer knowledge will prefer the wholly owned mode to others (Claver and Quer 2005, Canabal and White 2008). Caves (1996) argues that the choice of ownership structure for the affiliate can be significantly affected by the potential risk of misappropriation of the technological developments.

When the company is research intensive and property rights are weakly protected, foreign companies are more likely to establish WOS (Dikova and Witteloostuijn 2007), thus protecting the long-term viability and a company's competitive position from sharing or exposing core resources to a potential competitor. In case of partial ownership, the cost of co-ordinating, monitoring and defining the proprietary rights may outweigh the potential gains of a partnership with local agents.

Hypothesis 6: The more research intensive is the company, the more ownership it demands in its affiliate and, hence, the greater the probability of observing fully owned affiliates.

The marketing of goods is information-intensive. Moreover, the control of product quality is essential to maintain the reputation of a worldwide brand. It would be expected that in industries where sales-promotion expenditures are important, this might lead the company to be strongly concerned about free riding on its brand name. The reputation of the expanding company is also affecting the choice of the foreign mode of entry. Companies must invest heavily in advertising and their brand name to obtain a good reputation. This process of reputation building is time consuming and uncertain. High investments in reputation do not automatically lead to a good reputation. Each minor deviation from the behaviour that the company prescribes may have a disastrous impact on the company's reputation.

Taking a full ownership in the affiliate may be the way selected by the company to protect its intangible assets from misappropriation (Meyer et al. 2009b). The assumption implicit in this proxy is that money spent on advertising generates company specific assets in the form of brand recognition and product differentiation. We suggest that when companies operate in marketing intensive industries they are more likely not to share ownership (Kamal 2009). 
Therefore, companies that invest heavily in brand-name capital will avoid free riding by other companies by preferring WOS.

Hypothesis 7: The more marketing intensive is the company, the greater the probability of observing fully-owned affiliates.

The attractiveness of a foreign market depicted by its economic size has been a predominant factor in market selection as well as in the ownership mode choice of the firms from the TCE perspective (Brouthers and Brouthers 2003, Walkenhorst 2004, Cui and Jiang 2009, Vijayakumar et al. 2010). Firms are expected to enter attractive markets via WOS because it is expected that this alternative provides the greatest long term profit potential (Taylor et al. 1998, Brouthers 2002). The large market potential justifies the high risk and high control modes because of benefits of economies of scale and long-term market presence.

Large market size is assumed to lead to an enhanced resource commitment in the country but the expected increased returns will compensate the higher risks associated with the greater commitment of resources (Agarwal 1994). Higher returns are expected to come from the opportunity to gain economies of scale (Agarwal and Ramaswami 1992), based on the assumption that a high proportion of the cost of internationalisation is fixed (Buckley and Casson 1996, Chen and Hu 2002). Following the TCE rationale, market size can also be seen as a proxy for transaction frequency, which also enhances the firm's propensity to internalise (Williamson 1985). The empirical results of past IB studies about the impact of this important variable on ownership mode choice of firms are again quite mixed. The results in some studies like Barkema and Vermeulen (1998) support the positive relationship but the results in other studies like in Lu (2002) indicate a non-significant relationship and some results like in GomesCasseres (1989) and Herrmann and Datta (2002) indicate a negative relationship.

Hypothesis 8: Target country economic size is positively associated with the propensity of companies to choose WOS over JV.

An important indicator of the attractiveness of target country market used in the past studies following the transaction cost economics logic is the economic growth in the target country (Larimo 1993, Meyer and Peng 2005). Economic growth in the target country, however, differs somewhat from the other facets of market attractiveness e.g. from market size due to its dynamic nature. As an implication of this, economic growth is expected to lead to a negative relationship with the WOS alternative, because using the JV alternative the investing company can avoid the opportunity costs associated with the delayed entry (Hennart and Larimo 1998).

Empirical results concerning the influence of economic/market growth on WOS ownership choice are again mixed i.e. results in some studies indicate a positive and in other studies a negative relationship. The meta-analysis by Morschett et al. (2010) indicates, however, that the assumption of a negative relationship between market growth and a JV ownership mode receives statistically significant support. In CEE focused studies of ownership mode choice, Arslan and Larimo (2010) found high economic growth to result in the choice of WOSs by Finnish firms, while Dikova and van Witteloostuijn (2007) indicated a non-significant influence of economic growth on the ownership mode choice of Dutch firms in the CEE region. Therefore, based on the transaction cost theory argument, the findings of Arslan and Larimo (2010) and the meta-analysis by Morschett et al. (2010), it is expected that:

Hypothesis 9: Target country's economic growth is positively associated with the propensity of companies to choose WOS over JV.

One of the key issues addressed in TCE as well as RBV and IT is uncertainty and how it can 
impact the entry mode choices of the firms (Brouthers and Hennart 2007, Estrin et al. 2009). In case of high uncertainty, the transaction cost logic recommends a higher level of vertical integration. Due to bounded rationality, the anticipation of all future contingencies for which adaptations of a contract with a partner may be required is difficult under the conditions of strong uncertainty. Hence the internalisation of the activity may contribute to the absorption of external uncertainty (Klein et al. 1990, Agarwal 1994). However, TCE reasoning ignores the advantages of strategic flexibility (Brouthers et al. 2008b) and from the RBV perspective the high country risk implies the need to save firm resources and it suggests the avoidance of WOS (Agarwal and Ramaswami 1992, Contractor and Kundhu 1998). Target country risk has been used as a measure for external uncertainty in past IB studies (Zhao et al. 2004, Brouthers and Hennart 2007, Morschett et al. 2010); the results gave strong support for the increased preference of the JV alternative in cases of high country risk (Morschett et al. 2010). Empirical results of studies in transitional economies also support the general results as Brouthers (2002) and Brouthers et al. (2003) found that the higher country risk increased the preference of JV formation rather than WOS.

Hypothesis 10: Target country risk is negatively associated with the propensity of firms to choose WOS over JV.

Trade openness is used in several studies to explain the role of trade in FDI inflows (Gao 1996, Hoskisson et al. 2000). Theoretically, more open economies are more integrated to international markets. International companies may want to invest more in such countries to benefit from the easiness of international trade, so the probability of observing fully owned affiliates is greater, and therefore expect a negative sign for its coefficient.

Hypothesis 11: Target country trade openness is positively associated with the propensity of companies to choose WOS over JV.

Moreover, it is important to note that an important political-economic change that occurred in these regions during the past two decades, along with the transition to market economy, has been that many countries have become members of the EU (Zweynert and Goldschmidt 2006). Therefore, we also examine EU membership as a determinant ownership mode choice in the region, along with the above-mentioned important company, industry and country level determinants.

An important issue stressed by the IT refers to the level of advancement of the institutional environment in a particular target country (Peng 2003). The more advanced the environment is, the more stable the environment is, and this could be expected to lead to increasing preference for a WOS alternative. Institutional development can be used as an indicator of the progress of transition, but EU membership can be used as another indicator of progress, because the EU demands certain level of progress and stability before a new applicant country is accepted as a member. Dikova and van Witteloostuijn (2007) present somewhat different views about the impact of institutional advancement on ownership mode; stating that in an underdeveloped institutional environment characterised by weak property rights, WOS modes are more efficient because they reduce the transaction costs of unwanted dissemination. Arslan and Larimo (2010) did not find EU membership as a significant variable for the ownership strategy of companies in CEE. Based on the discussion presented, the literature offers different perspectives about the impacts of EU membership of a CEE or SEE country on the ownership mode choice of investing companies.

Hypothesis 12: EU membership of a target country is positively associated with the propensity of companies to choose WOS over JV. 


\section{Methodology}

Following Meyer et al. (2009a), we investigate the impact of market-supporting institutions on business strategies by analysing the entry strategies of foreign companies entering the emerging economies. We apply and advance the institution-based view of strategy by integrating it with RBV and TCE considerations. Alternative modes of entry allow companies to overcome different kinds of market inefficiencies related to both the characteristics of the resources and to the institutional context. We argue that the institutional development in the emerging economies directly affects the entry strategies and the companies' needs for local resources impact the entry strategies in different ways in different institutional contexts. In essence, we advocate an integrative perspective calling not only for explicit considerations of institutional effects, but also for their integration with resource-based and transaction cost considerations. This research thus responds to the call issued by Meyer and Peng (2005), Wright et al. (2005), Peng (2008), and Yamakawa et al. (2008) for more integration between the institutional, resource-based and transaction cost views.

The economies of Bulgaria, Romania, Poland and Hungary are selected because they show substantial variation in formal and informal institutions. The cross country diversity implies that data pooled provide significant variations in terms of institutions that may affect entry strategies of foreign investors. The company-level data used have been retrieved from two commercial databases, ICAP and Amadeus. After deleting companies with incomplete and missing data, an unbalanced panel data was constructed which included 285 European companies that have invested in SEE and CEE between 1995 and 2015. The ownership mode choice of the sample companies consisted of $146 \mathrm{JV}$ and 139 WOs, focusing only on the ownership mode at entry, thus any later changes in the ownership arrangement of the same investment are not included. Across regions, variation can be observed; in SEE, 57 have invested in Romania (36 JV and 21 WOS) and 64 in Bulgaria (47 JV and 17 WOS), while for companies reporting FDI in CEE, 76 companies have invested in Hungary (27 JV and 49 WOS) and 88 in Poland (36 JV and 52 WOS). Although the existing literature in transition markets suggests that the acquisitions are confronted with many challenges that incur high transaction costs (Dikova and van Witteloostuijn 2007, Meyer et al. 2009b, Haar and Marinescu 2014, Poznan et al. 2015, Choromides 2017), yet WOS is the most popular choice of companies expanding into CEE.

Considering our research theme, it is our intention to select different sized companies, with diverse activities in different industries. The base population covers manufacturing as well as service companies headquartered in EU; both under European ownership and subsidiaries of non-European companies. The sample came not from a single industry and hence the generalisability of the results is not limited. Thus the characteristics underlying the different companies in our sample vary considerably, and for this reason the biases may cancel one another out to an extent (Simon 1969). In this way, the emerging theory may be tested in different settings, extending it and improving its external validity. Though we have considered the idiosyncrasy of the service companies as discussed by Buckley et al. (1992), Li (1994), and Brouthers and Brouthers (2003), we have decided to include them in our research, following the example of lammarino and Pitelis (2000), and Uhlenbruck and De Castro (2000), who also included service companies in their research on FDI. Although we have tried to include a dummy variable 0,1 to differentiate between the manufacturing and the service companies, yet the results were statistically insignificant and not robust. Also gathering data during the same time period in all cases has ensured validity issues and the comparability across companies and countries. The use of parallel cases from the four transitional countries also helps to guard against biases within any country, especially because cross-country comparisons are facilitated by efforts to match some companies across countries by sector, size or by ownership type. However, caution must be also exercised in drawing cause-effect inferences from the study because of the use of cross-sectional data. 


\begin{abstract}
Location factors are not stressed, but they are controlled (partially) since only homogeneous areas are studied, following the proposition of Woodcock et al. (1994) and Nitsch et al. (1996). Their common experience under the central planning regime suggests that they are all members of a broader, clearly identifiable class of social-political-economic systems. Their transition toward democratisation and market-based economies, albeit with different speed and pace, and becoming full members of the EU have led to similar changes in their institutional infrastructure (Fig. 2), thus, we are able to absorb any specific locational differences (Estrin and Uvalic 2014). Both Bulgaria and Romania joined the EU in 2007, and have made considerable progress in promoting the private sector development. Since 1995, their institutional and regulatory frameworks have been reformed at various extents, but following similar patterns. Hungary and Poland joined the EU in 2004, and their transition pattern towards the free market economies has been similar to Bulgaria's and Romania's (Heritage Foundation 2017a). Following the proposition of Dauti (2015), we keep out from our analysis some other transitional countries (e.g. Serbia, Croatia, Bosnia and Herzegovina) because circumstances throughout much of the period considered in this study make them special cases that would need country specific explanations.
\end{abstract}

The quality of institutions and regulations in the four transitional economies is expected to affect the investment decision of foreign investors. Overall, weak institutions are assumed to positively affect JV, while high quality institutions are expected to positively affect WOS. In order to examine the role that the quality of regulations and institutions has as determinants of ownership structure, a group of explanatory variables is employed (Table 1). We proxy the strength of market-supporting institutions by ten items of the Economic Freedom index developed by the Heritage Foundation. The Index of Economic Freedom from the Heritage Foundation is an indicator which is calculated for 186 countries and it takes into account 50 independent variables, which are broken down into ten different categories and their operational definitions are available from the Heritage Foundation (2017b). The index is graded on a scale of 0 to 100 , with higher values indicating more rigid regulations. The results from these variables were used to measure institutional distances in the SEE and CEE countries. Following Xu et al. (2004), the institutional scores of the countries are calculated by the numerical average of the items used to measure them. The regulative and normative institutional distance is measured by the difference between the scores of host countries and EU countries.

To control for any possible correlation problems since various institutional variables measure similar economic freedoms, we group those institutional variables that measure similar economic freedoms (Daude and Stein 2007). The average of Property Rights and Government Integrity will be used in the equation as an indicator on Rule of Law, the average of Tax Burden and Government Spending will be used as an indicator on Government Size, the average of Business Freedom, Labor Freedom and Monetary Freedom will be used as an indicator on Regulatory Efficiency, while the average of the remaining variables, Trade Freedom, Investment Freedom and Financial Freedom will be used as an indicator on Open Markets.

Following Kaynak et al. (2007), and Arslan and Larimo (2010), we are using a bionomial logistic regression model to address the ownership mode choice of the companies; to test our hypotheses, to analyse the impact of the selected independent variables on the ownership mode and to explain the ownership mode choice of foreign investors in SEE and CEE economies. In general, the model can be expressed as:

$$
P(\mathrm{yi}=1)=1 /(1+\exp (-\alpha-X i B))
$$

where $y i$ is the dependent variable, $X i$ is the vector of independent variables for the ith observation, $\alpha$ is the intercept parameter and $B$ is the vector of regression coefficients 
(Amemiya 1981). The dependent variable has value of 1 if the ownership mode choice is JV; therefore, a positive regression coefficient indicates that a particular variable increases the probability of $\mathrm{JV}$ formation in the ownership strategy of a company.

Table 1

Definitions of variables

\begin{tabular}{|c|c|c|c|}
\hline \multicolumn{2}{|r|}{ Company Characteristics } & Unit & Source \\
\hline $\begin{array}{l}\text { FDI } \\
\text { MODE }\end{array}$ & $\begin{array}{l}\text { Dummy variable, } 0 \text { if the establishment mode is } \\
\text { WOS, } 1 \text { in the event the foreign subsidiary is a JV }\end{array}$ & {$[\#]$} & \multirow{6}{*}{$\begin{array}{l}\text { ICAP } \\
\text { AMADEUS }\end{array}$} \\
\hline LABOUR & Number of sales/employees & $\begin{array}{l}{[\% \text { of }} \\
\text { rate] }\end{array}$ & \\
\hline RESRC & $\begin{array}{l}\text { The resource intensity is measured by a dummy vari- } \\
\text { able, equal to } 1 \text { if the main economic activity of the } \\
\text { company is in a resource-intensive industry and } 0 \\
\text { otherwise }\end{array}$ & [\#] & \\
\hline R\&D & $\begin{array}{l}\text { Technological intensity is proxied by the percentage } \\
\text { ratio of } R \& D \text { expenditures over sales }\end{array}$ & $\begin{array}{l}{[\% \text { of }} \\
\text { rate] }\end{array}$ & \\
\hline ADVERT & $\begin{array}{l}\text { Advertising intensity is proxied by the ratio of advertis- } \\
\text { ing expenditures/sales of the parent company, and it } \\
\text { attempts to control for possible sales promotion ef- } \\
\text { fects on the ownership choice }\end{array}$ & $\begin{array}{l}{[\% \text { of }} \\
\text { rate] }\end{array}$ & \\
\hline GEOGR & $\begin{array}{l}\text { Number of different geographical markets in which } \\
\text { the parent company is active }\end{array}$ & {$[\#]$} & \\
\hline CAPINT & $\begin{array}{l}\text { Capital intensity is proxied by the ratio of total assets/ } \\
\text { sales }\end{array}$ & {$[\#]$} & \\
\hline \multicolumn{2}{|r|}{ Country Variables } & Unit & \multirow{6}{*}{$\begin{array}{c}\text { Source } \\
\text { UNCTAD, } \\
\text { Euromoney } \\
\text { (country risk } \\
\text { ratings), The } \\
\text { Heritage } \\
\text { Foundation } \\
\text { (Index of Eco- } \\
\text { nomic Free- } \\
\text { dom) }\end{array}$} \\
\hline GDP & Total GDP in the year of investment & $\begin{array}{l}{[\%} \\
\text { rate] }\end{array}$ & \\
\hline $\begin{array}{l}\text { GDP } \\
\text { GROWTH }\end{array}$ & $\begin{array}{l}\text { The annual percentage change rate of GDP in the } \\
\text { target country in the year proceeding the investment }\end{array}$ & $\begin{array}{l}0 \% \\
\text { rate }]\end{array}$ & \\
\hline $\begin{array}{l}\text { TRADE } \\
\text { OPEN- } \\
\text { NESS }\end{array}$ & $\begin{array}{l}\text { The total volume of exports and imports as a share of } \\
\text { GDP }\end{array}$ & $\begin{array}{c}{[\%} \\
\text { rate }]\end{array}$ & \\
\hline RISK & The country risk in the year preceding the investment & [\#] & \\
\hline $\begin{array}{l}\text { EU AC- } \\
\text { CESS }\end{array}$ & $\begin{array}{l}\text { Dummy variable, } 0 \text { if the investment made before EU } \\
\text { Accession of the host country, and } 1 \text { for the invest- } \\
\text { ment after EU accession }\end{array}$ & [\#] & \\
\hline
\end{tabular}

\section{Results and Discussion}

Table 2 shows that our model has a good explanatory power because the chi-square value is significant at $p<0.001$ level. Hair et al. (1998) recommend analysing the fit of the logistic regression model to the data by using correct classification rate criteria. Model 1 (CEE) correctly classified $61.4 \%$ of the cases, while Model 2 (SEE) correctly classified $62.7 \%$ of cases respectively, providing good classification accuracy comparable to previous studies (Kaynak et al. 2007). The predictions are adequate given how unbalanced and non-homogeneous - by including both manufacturing and service companies - our sample has been (Greene 1997). 
The explanatory power of all models is also good, as their Chi-squared values are all significant.

Table 2

Logistic Regression Estimates of Ownership Mode Choice (CEE results in parenthesis)

\begin{tabular}{|c|c|c|}
\hline Variables & CEE & SEE \\
\hline FDI MODE & $-0.627^{* \star *}$ & $0.782^{* \star *}$ \\
\hline GDP & $-0.0054^{\star *}$ & $0.033^{\star *}$ \\
\hline GDP GROWTH & $-0.0079^{* *}$ & $0.052^{\star *}$ \\
\hline TRADE OPENNESS & -0.588 & -1.431 \\
\hline RISK & $-0.051^{* *}$ & $0.038^{* *}$ \\
\hline EU ACCESS & -0.0166 & 0.154 \\
\hline LABOUR & $-1.673^{* \star *}$ & $-0.418^{*}$ \\
\hline RESRC & $-0.093^{* *}$ & $0.792^{\star \star \star}$ \\
\hline R\&D & $-0.753^{*}$ & $1.673^{* * *}$ \\
\hline ADVERT & $-1.812^{* *}$ & $0.741^{*}$ \\
\hline GEOGR & $-0.816^{\star \star \star}$ & $0.645^{\star *}$ \\
\hline RULE OF LAW & $-0.204^{* * *}$ & $0.182^{* * *}$ \\
\hline GOVERNMENT SIZE & $-0.544^{* * *}$ & $0.601^{* * *}$ \\
\hline REGULATORY EFFICIENCY & $-0.379^{*}$ & $0.128^{*}$ \\
\hline OPEN MARKETS & $-0.132^{*}$ & $0.286^{*}$ \\
\hline Constant & 0.300 & 0.349 \\
\hline $\mathrm{N}$ & 164 & 121 \\
\hline Model ${ }^{x^{2}}$ & $55.958^{* \star *}$ & $56.174^{\star * *}$ \\
\hline 2 Log Likelihood & 403.36 & 412.25 \\
\hline Nagelkerke ${ }^{R^{2}}$ & 0.084 & 0.174 \\
\hline Correctly Classified (\%) & 61.4 & 62.7 \\
\hline
\end{tabular}

Significance levels: $p<0.01^{* \star *}, p<0.05^{\star \star}, p<0.1^{*}$

We observe that three variables - country risk, establishment mode, and economic growth have a statistically significant impact on the ownership mode choice in CEE. We also observe that these variables have a negative sign, which indicates the probability of not choosing JV in the ownership strategy. We believe that companies entering countries with a high level of economic growth prefer WOS formation due to the market potential and business opportunities offered by those markets. To appropriate these benefits, firms are often likely to choose WOS, rather than JV (Agarwal and Ramaswami 1992, Brouthers 2002). These results are consistent with the findings of Fung et al. (2002), Baniak et al. (2005) and Al Nasser (2007), who conclude that the macroeconomic growth potential of the economy is among the main determinants of IB strategy. The impact of country risk on preference of WOS formation can be explained by referring to the fact that companies may desire to have more control on the operations of subsidiaries in the countries with high risk. On the contrary for SEE countries, the choice of JV can be explained by referring to the investing companies' desire to share risks and costs in a risky environment (Agarwal and Ramaswami 1992, Brouthers et al. 2008a). In addition, the finding concerning the economic growth of the target country increasing the probability of JV is 
not similar to the findings of previous studies like Agarwal and Ramaswani (1992), Brouthers (2002), Arslan and Larimo (2010), Morschett et al. 2010. A reason that companies prefer to establish a JV, can be that they were motivated by survival instincts thus they opt for shared ownership to quickly counter the potential loss of regional market share to other foreign companies (Larimo and Nguyen 2015). The threat and costs associated with the potential loss of regional market share to competitors would be greater than the additional costs of assimilation of new routines into the overall corporate system, as would be necessary under a WOS. The negative sign of the EU dummy shows that the EU accession of the CEE and SEE countries in our sample has influenced the preference for the formation of WO and JV subsidiaries respectively, though it does not receive significant statistical support.

Regarding the institutional and regulatory variables, it is evident from the coefficients that the Rule of Law and Government Size are the explanatory variables with the highest statistical significance at less than $1 \%$ level, and appear to have an effect on ownership mode choice of companies. The indicators related to Regulatory Efficiency and Open Markets appear to play a less, still statistically significant role respectively in affecting the decision on ownership mode choice. Therefore, we conclude that the high institutional distance in the CEE region results in the formation of WOS (Yiu and Makino 2002, Xu et al. 2004, Kaynak et al. 2007, Meyer et al. 2009a). It can be argued that the cost and uncertainty in shared ownership structure are greater in culturally distant target countries due to the volatility of the environment in the target country (Brouthers and Brouthers 2000). Accordingly, companies investing in culturally distant target countries are more likely to prefer the formation of WOS in order to exert greater control over their subsidiaries in order to minimize transaction costs and risk (Hill et al. 1990). However, the opposite is truth for the SEE region; low institutional distance between the home and host countries leads companies to prefer JV in the ownership strategy. Because of the high non-recoverable costs, FDI is particularly prone to any form of instability; given the lower score for the quality of institutions evidence supports that they are influenced by the uncertainty arising from the political volatility, the effectiveness of the legal system and the extent to which the laws on property rights are enforced (Stern 2003). According to Zweynert and Goldschmidt (2006) and Kshetri (2010), Poland and Hungary have been more successful in creating institutions existing in other market economies, while Bulgaria and Romania have been less successful on this front (Bitzenis 2009). Therefore, the companies' ownership strategy is also expected to be influenced by these differences in regulative and legal infrastructures within SEE and CEE countries because the companies' preference for the formation of WOS may decrease in a country with less-developed regulative institutions (Peng 2003). Therefore, the formation of $\mathrm{JV}$ offers investing companies a viable option to commit fewer resources and to consequently reduce the risk (Tihanyi et al. 2005).

The results show that a company with high labour costs will opt for the WOS mode. This finding is interesting if we consider that post-socialist economies are experiencing a major industrial restructuring process, which increase the post-investment costs for investors. Increasing productivity often requires to lay off a large number of employees. This is costly to organise and it could severely damage the investors' local reputation. We can suggest that the higher the labour intensity of an industry, the higher the post-investment costs due to the overemployment problem. Therefore, they preferred WOS to JV, since acquisition provides more managerial control compared to a JV. Thus they have more freedom and autonomy in the relations with the labour force and they can reduce its labour force more easily, than in a JV where the influence of the local partner may be stronger (Monteverde and Teece 1982, Anderson and Schmittlein 1984) and investing companies would have to tackle and cope with the corporate difference of the local partner (Barkema et al. 1996).

Companies with high R\&D intensity tend to internalise their transactions having complete control over their proprietary know-how in order to preserve and/or best exploit the knowledge, given the imperfections in the external markets for technology. Transferring tacit or poorly 
protected proprietary know-how to their subsidiaries, the pricing and the enforcement of contracts with potential JV partners will be fraught with difficulties. According to TCE, the loss of control increases the transaction costs in the case of a transfer of specific assets in combination with the possible opportunistic behaviour by the partner(s) (Makino and Neupert 2000, Yiu and Makino 2002, Zhao et al. 2004). Based on the statistical significance of the propensity to form a WOS, we argue that a company's transfer of technological know-how varies directly with its R\&D intensity, thus there will be an inverse relationship between the $R \& D$ intensity and the propensity to JV. The decision to establish a WOS can be justified since technology transfer influences the subsidiary ownership choice and performance not only because a transfer is difficult and costly but also because the transferred technology may not always be successfully commercialised in the local marketplaces, and since in a JV the foreign partner might lack control over the networking and distribution system necessary for the commercialisation of technology, that leaves WOS as the most appropriate for the control and commercialisation of technology in the host market (Brada 1981, Williamson 1981). On the contrary for the SEE, the companies did not opt for that entry mode; a plausible explanation might be that these companies are not transferring to their subsidiaries the complex company specific technological knowledge of recent origin (Williamson 1981), thus there is a low possibility to be significantly affected by the potential risk of misappropriation of the technological developments (Caves 1996), by sharing or exposing core resources to a potential competitor. Thus for these companies the cost of co-ordinating, monitoring and defining the proprietary rights might not outweigh the potential gains of a partnership with local agents (Davidson 1982).

The variable RESRC affects positively the probability of observing JV. It seems plausible that the access to the best resources is already in the hands of local companies, and that the best way to access these resources is to invest in the target country company that holds them. In these companies, the need for complementary inputs appear to be a dominating over considerations concerning the post-investment costs of restructuring and integrating the local company (Gomes-Casseres 1989, 1990). We suggest that companies that formed JV are strongly depended on local inputs at the time of the initial investment since the transportation costs for raw material were high and trade barriers inhibit international trade at that time. Even to supply the local markets, they needed access to local raw materials. Thus, they preferred to form JV. In this case, a JV simply provided a concessionary right to exploit a resource. Under the conditions of systemic upheaval towards the transition to the market economy access to essential and often scarce material inputs was eased by forming $\mathrm{JV}$, thus inheriting local networks, which enjoy privileged links with primary materials producers. On the contrary, companies in CEE seem to be less dependent in local resources, suggesting that either they do not operate in industries processing natural resources (Williamson 1981), or they may have found a way to efficiently contract out the required resources and set up WOS thus use the joint venture channel to gain access to them. The redeployment of resources from the home country can in part offset the costs of entry, reducing the entry costs of WOS vis-à-vis JV. Therefore, WOS could be more feasible for companies with resources that can be transferred and constitute core competences of the new business subsidiary in CEE. Such resources can be employed in the subsidiary without incurring the initial sunk costs of their development, and the subsidiary can attain competitiveness from competences and resources shared with the investing company. This makes WOS a natural choice for companies with a strong competitive advantage. Companies that can transfer their resources wish to build a subsidiary, which replicates the production technology and/or the organizational structure of their existing operation.

The variable ADVERT performs as it was expected but only in the CEE region. The sign of its estimated coefficient suggests that marketing intensive companies are more likely to prefer WOS. Companies invest heavily in advertising to obtain a good reputation. This process and experience of reputation building is time consuming and uncertain. This process and 
experience, which are often applicable to new markets, may be difficult to communicate to a JV partner. Full ownership is a way to avoid having to persuade the partner that they are choosing the optimal level and mix of advertising expenditures. High investments in reputation do not automatically lead to a good reputation. Each minor deviation from the behaviour that they prescribe may have a disastrous impact on their reputation. Therefore, companies that invest heavily in brand-name capital will avoid free riding by other companies using the names in an inconsistent manner thus diluting or confusing the international position of the brands. Highcontrol entry modes are considered to be the most efficient governance structures in situations where the risk of free riding is high (Kamal 2009). On the contrary for SEE region, the companies did not opt for that entry mode. A reason might be that they distributed in the market heavily advertised products that could be unsophisticated goods, which local agents are capable of handling, making low control appropriate for protecting brand names from degradation by free-riders or preventing the local operation from using the names in an inconsistent manner thus diluting the international position of the brands. Therefore, a transaction cost theory of entry choice is not supported, favouring JV for the purpose of brand label or product adaptation (Caves 1996).

The variable GEOGR performs as it was expected in the CEE region in line with previous studies that mentioned that the internationally experienced companies prefer to establish a WOS (Das and Teng 2000, Evans et al. 2008, Li and Meyer 2009, Chiao et al. 2010, Lee 2010). International experience would lead to better capabilities to manage and integrate a WOS. In their internationalisation process, companies would make incrementally stronger commitments along various dimensions. Knowledge of foreign markets is experiential knowledge, which cannot be taught. It can only be acquired through experience and active involvement in foreign markets. Such knowledge is essential for resource commitment because it enables the recognition of business opportunities and it reduces market uncertainty (Dierickx and Cool 1989, Chang 1995). Therefore, past commitment and accumulated international market experience determines current activities as well as future resource commitments. Companies with related experiences can organise a given transaction at lower costs, and share their resources, such as international management cadres and organisational capabilities, across operations. Their experience reduces the costs of internal organisation, and thus it facilitates internalisation. Hence, the marginal costs of an additional entry are lower. Another reason can be that these companies do have the international business experience required to bear the risks associated with a wholly owned affiliate and to integrate foreign subsidiaries of diverse managerial nationalities into their systems, thus they find it more compatible to form a JV to share the risks (Chang 1995, Das and Teng 2000). Although JV arrangements may be more appropriate from a risk reduction perspective, they may not allow the strategic control and flexibility that are needed to secure long-term competitiveness, and to cope with the institutional transition going on in those markers. Regarding the SEE, we observe a positive effect of the increase in international experience. Experienced companies would find a weaker need to depend on a WOS to deal with the unexpected contingencies. The greater international business experience may enable the companies to deal effectively with the costs and uncertainty associated with accepting equity partners and to become more willing to choose the shared ownership (Dikova and Witteloostuijn 2007). Another explanation can be that these companies are more concerned with the international strategic position than with the transaction costs associated with a given market (Porter and Fuller 1986), or they prefer to share the risk with the local partners and to avoid costly mistakes in the new environment. Empirically, Gatignon and Anderson (1988), Erramilli (1991) and Agarwal (1994) support this position. Moreover, the local partners in the $\mathrm{JV}$ can also be helpful in overcoming the unfamiliarity arising from the high normative distance between the foreign companies' home and host countries (Kaynak et al. 2007).

These findings also confirm the findings of previous studies that used these variables to 
address the ownership mode choice of the companies in transition economies (Dikova and van Witteloostuijn 2007) as well as in the generally emerging economies (Arslan 2011). Therefore, based on TCE and RBV and the strength of market conforming values in the target country, companies receive empirical support for their impacts on ownership mode choice in both regions. Although the transfer of organisational practices, policies, resources and strategies to an acquired business unit operating under local rules in a distant market can be problematic for the acquiring investor (Kostova and Roth 2002), our results for CEE countries suggest that these concerns did not deter the foreign investors to opt for a WOS.

\section{Conclusions}

The purpose of our study was to examine the impacts of institutional distance and company ownership characteristics on the ownership strategy of companies in the former transitional economies of SEE and CEE regions. This study originally presented the evolution of FDI in the two regions briefly. The focus then turned to the analysis of the role that the quality of institutions has in determining the ownership structure. In this context, the relevant literature was explored and conclusions were drawn in order to discuss the status of the institutions in SEE and CEE. Using company and country-level data during 1995-2015, the significance and the effectiveness of a broad set of institutional and regulatory variables as factors that might have an effect on the ownership decision in the region and whether the contribution of regulatory and institutional factors driving ownership structure in the former transitional economies of SEE are different than of CEE was explored. Overall, the results confirm the universal belief that the quality of institutions and regulations in a country are important factors in the decision of ownership structure. In addition, company and country explanatory variables had a statistically significant influence on the ownership structure decision.

We hypothesised the probability of the use of JV or WOS in relation to the institutional distance and the ownership characteristic of the company. Our dataset of 285 companies in 2 SEE and 2 CEE countries allowed us to perform a robust analysis of our hypotheses. Our study contributes to the entry mode choice literature addressing the impacts of different aspects of institutional distance on the ownership strategies. The empirical context of FDI in SEE and CEE countries appears to be really useful because of the relatively large differences in the regulative and normative institutions of these countries and their unique history of transition to the market economies.

Our results indicate that the institutional distance's impact on the ownership strategy is statistically significant. From our control variables, we found out that the establishment mode, the country risk and the economic growth in the host country are also significant. Finally, we found evidence that foreign investors select their ownership share based on R\&D and technology, the resource intensity of the company, the labour and advertising intensity, and the geographical diversification of the international business activity.

In response to the recent calls for more integration between the institution-based and the resource-based perspectives in the emerging economies (Peng 2003, Meyer and Peng 2005 , Wright et al. 2005, Yamakawa et al. 2008), this article enriches the institution-based view of business strategy and it makes three contributions - theoretical, empirical, and methodological, by providing a conceptual analysis of the relationship between the institutional frameworks and the entry strategies. Theoretically, we argue that the level of development of an emerging economy's market-supporting institutions directly influences the entry strategies and that institution-based considerations complement the resource-based considerations when crafting entry strategies. Therefore, we enrich an institution-based view of business strategy (Estrin et al. 2008, Gelbuda et al. 2008, Peng 2008) by providing a fine-grained analysis of the relationship between institutional frameworks and entry strategies. Empirically, and in line with the literature, we argue that institutions moderate resource-based considerations when crafting 
entry strategies and we find that the stronger the institutional framework, the more likely investors are to choose WOS (Meyer 2001b, Brouthers and Brouthers 2003, Wan and Hoskisson 2003, Kedia et al. 2006, Dikova and van Witteloostuijn 2007). Our primary hypotheses suggest that institutional development reduces the need for a JV partner and thus it facilitates WOS entry, while resource needs increase the preference for both WOS and JV. Finally, by amassing a sample from four diverse but relatively under-explored countries, we extend the geographic reach of empirical research on the emerging economies.

Our study also has certain limitations. First, though our indicators of regulative and normative institutional distance provide objective country-level measures of these concepts, they rely solely on the Index of Economic Freedom developed by the Heritage Foundation, which could be considered as a limitation. Moreover, our study concentrates on FDI made only by European companies, which could also be considered as a limitation. However, conversely, the focus on FDI made by these companies provides an opportunity to analyse the impacts of regulative institutional distance and the normative institutional distance on the ownership strategy, from the European companies' perspective.

In addition, our study is limited in its static perspective, implicitly assuming that ownership strategies are constant over time. The ownership mode choice of the sample companies in target countries is focusing only on the ownership mode at entry, thus any later changes in the ownership arrangement of the same investment are not included. In contrast, a group of strategy process scholars emphasized the dynamic nature of ownership strategy (Nelson and Winter 1982, Mintzberg and Quinn 1992). These researchers argue that companies adjust their ownership strategy to accommodate the changes in the internal and external environments (Nelson and Winter 1982, Chang 1996, Greenwood and Hinings 1996). In addition, it would be quite interesting to examine any differences in the significance of determinants of ownership choice of the early investments of foreign firms (during the 1990s) vs. later investments (during the 2000s); this will enhance the academic contribution of the current research. It has been mentioned in the past literature that these regions went through a period of relatively high uncertainty in the 1990s due to the transition to market economies which also affected the strategies of foreign firms (Peng 2003).

While location and industry factors were partially controlled, a more fine-grained analysis which controls for these and various other variables would provide further insight. The relationship between company-specific factors, country factors, transactions, entry mode, and finally, performance, is much more complex than the methodology employed here is hoping to reveal. Our empirical evidence provides support for the theoretical model developed in this study. It must be acknowledged, however, that this study represents only an exploratory investigation of an otherwise complex causal relationship. As such, it establishes a base theoretical model and evidence upon which subsequent work can be based. In addition, industry-specific factors, such as barriers to entry and exit, may improve the explanatory capacity of the model.

For future research, we suggest that the sample should be divided in two parts, before and after the EU accession, and then the influences of regulative and normative institutional distance on the ownership strategies. This would especially be useful in the context of many SEE and CEE countries, where market reforms have been implemented successfully (Zweynert and Goldschmidt 2006), and to compare them with countries wherein the reform process has been relatively slower, or, to give a more regional dimension, we could compare the context of the SEE countries to the context of CEE countries. By doing so we could differentiate the early stages of the transition to market economies from the later ones, as risk and uncertainty around market economy institutions were higher in the early stages, which also impacted the strategies of the companies operating there (Peng 2003, Meyer and Peng 2005, Zweynert and Goldschmidt 2006). The theoretical implication of this links to the fact that timing is an important element for testing the established IB theories in transition and emerging 
economies. Hence, the timing issue needs further region specific exploration in the future because it will also augment the scholarly understanding of market entry mode choices of the companies from the perspective of different IB theories.

In addition, it would be very useful to compare and contrast the findings from the investors of other regions with the experience and the strategic decisions of the European companies. By including an expanded dataset comprising the FDIs made by the companies from other regions, the findings of the study can be more easily generalised due to the multiple home countries of the investing companies. Moreover, future research has the potential to advance the use of institutional distance in international business studies by addressing its impacts on the company's diversification strategies, management of acquisitions, and divestment decisions.

\section{References}

ACEMOGLU D., JOHNSON S. (2005), Unbundling institutions, Journal of Political Economy 113 (5), 949-995.

ACEMOGLU D., JOHNSON S., ROBINSON J. A. (2005), Institutions as a fundamental cause of long-run growth, in: Aghion P., Durlauf S. N. (eds.), Handbook of Economic Growth, vol. 1A, Elsevier, Amsterdam, pp. 386-472.

ADDISON T., HESHMATI A. (2003), The new global determinants of FDI flows to developing countries: The importance of ICT and democratization, UNU/WIDER, Helsinki.

AGARWAL S. (1994), Socio-cultural distance and the choice of joint ventures: a contingency perspective, Journal of International Marketing 2 (2), 63-80.

AGARWAL S., RAMASWAMI S. N. (1992), Choice of foreign market entry mode: Impact of ownership, location and internalisation factors, Journal of International Business Studies $23(1), 1-27$.

AIZENMAN J., SPIEGEL M. M. (2006), Institutional efficiency, monitoring costs and the investment share of FDI, Review of International Economics 14 (4), 683-697.

AKHTER S. H. (1993), Foreign direct investments in developing countries: The openness hypothesis and policy implications, The International Trade Journal 7 (6), 655-672.

AL NASSER O. M. (2007), The Determinants of the U.S. Foreign Direct Investment: Does the Region Matter?, Global Economic Review 36 (1), 37-51.

ALI F. A., FIESS N., MACDONALD R. (2010), Do institutions matter for foreign direct investment?, Open Economies Review 21 (2), 201-219.

AMEMIYA T. (1981), Qualitative response models: a survey, Journal of Economic Literature 19 (4), 1483-1536.

ANDERSON E., GATIGNON H. (1986), Modes of Foreign Entry: A Transaction Cost Analysis and Propositions, Journal of International Business Studies 17 (3), 1-26.

ANDERSON E., SCHMITTLEIN D. C. (1984), Integration of the sales force: an empirical examination, The Rand Journal of Economics 15 (3), 385-395.

APERGIS N., KATRAKILIDIS C. (1998), Does inflation uncertainty matter in foreign direct investment decisions? An empirical investigation for Portugal, Spain and Greece, RISEC International Review of Economics and Business 45 (4), 729-744.

ARREGLE J.-L., HEBERT L., BEAMISH P. W. (2006), Mode of international entry: The advantages of multilevel methods, Management International Review 46 (5), 597-618.

ARSLAN A. (2011), Institutional distance: market conforming values in the host country and foreign direct investment choices of multinational enterprises, Vaasan yliopisto, Vaasa.

ARSLAN A., LARIMO J. (2010), Ownership strategy of multinational enterprises and the impacts of regulative and normative institutional distance: evidence from Finnish foreign direct investments in Central and Eastern Europe, Journal of East-West Business 16 (3), 179-200.

ASIEDU E., VILLAMIL A. P. (2000), Discount factors and thresholds: Foreign 
investment when enforcement is imperfect, Macroeconomic Dynamics 4 (1), 1-21.

BAEK K., QIAN X. (2011), An Analysis on Political Risks and the Flow of Foreign Direct Investment in Developing and Industrialized Economies, Economics, Management and Financial Markets 6 (4), 60-91.

BANIAK A., CUKROWSKI J., HERCZYNSKI J. (2005), On the determinants of foreign direct investment in transition economies, Problems of Economic Transition 48 (2), 6-28.

BARKEMA H. G., BELL J. H. J., PENNINGS J. M. (1996), Foreign entry, cultural barriers, and learning, Strategic Management Journal 17 (2), 151-166.

BARKEMA H. G., VERMEULEN F. (1998), International expansion through start up or acquisition: a learning perspective, The Academy of Management Journal 41 (1), 7-26.

BARTHEL F., BUSSE M., NEUMAYER E. (2010), The impact of double taxation treaties on foreign direct investment: evidence from large dyadic panel data, Contemporary Economic Policy 28 (3), 366-377.

BECCHETTI L., HASAN I. (2008), The effects of regional integration: Impact on real effective exchange rate volatility, institutional quality and growth for MENA countries, in: GuhaKhasnobis B., Mavrotas G. (eds.), Financial Development, Institutions, Growth and Poverty Reduction. Studies in Development Economics and Policy, Palgrave Macmillan, London, pp. 260-286. York.

BEIM D. O., CALOMIRIS C. W. (2003), Emerging Financial Markets, McGraw Hill, New

BÉNASSY-QUÉRÉ A., COUPET M., MAYER T. (2007), Institutional determinants of foreign direct investment, The World Economy 30 (5), 764-782.

BENGOA M., SANCHEZ-ROBLES B. (2003), Foreign direct investment, economic freedom and growth: new evidence from Latin America, European Journal of Political Economy 19 (3), 529-545.

BERTONCELJ A., DERMASTIA M., KESIC D. (2007), Knowledge-based industry after market liberalisation: the case of the local pharmaceutical industry in Central and Eastern Europe, International Journal of Technology and Globalisation 3 (2-3), 263-277.

BERGER A., BUSSE M., NUNNENKAMP P., ROY M. (2011), More stringent BITs, less ambiguous effects on FDI? Not a Bit!, Economics Letters 112 (3), 270-272.

BERGER A., BUSSE M., NUNNENKAMP P., ROY M. (2013), Do trade and investment agreements lead to more FDI? Accounting for key provisions inside the black box, International Economics and Economic Policy 10 (2), 247-275.

BEVAN A. A., ESTRIN S. (2004), The determinants of foreign direct investment into European transition economies, Journal of Comparative Economics 32 (4), 775-787.

BEVAN A., ESTRIN S., MEYER K. (2004), Foreign investment location and institutional development in transition economies, International Business Review 13 (1), 43-64.

BITZENIS A. (2009), The Balkans: foreign direct investment and EU accession Ashgate Publishing, Farnham.

BITZENIS A., TSITOURAS A., VLACHOS V. A. (2009), Decisive FDI obstacles as an explanatory reason for limited FDI inflows in an EMU member state: The case of Greece, The Journal of Socio-Economics 38 (4), 691-704.

BLONIGEN B. A. (2005), A review of the empirical literature on FDI determinants, Atlantic Economic Journal 33 (4), 383-403.

BRADA J. (1981), Technology Transfer by means of industrial cooperation: a theoretical appraisal, in: Marer P., Tabaczynski E. (eds.), Polish-US Industrial Cooperation in the 1980s: Findings of a Joint Research Project, Indiana University Press, Bloomington.

BROUTHERS K. D. (2002), Institutional, cultural and transaction cost influences on entry mode choice and performance, Journal of International Business Studies 33 (2), 203-221. BROUTHERS K. D., BROUTHERS L. E. (2000), Acquisition or greenfield start-up? Institutional, cultural and transaction cost influences, Strategic Management Journal 21 (1), 89 97.

BROUTHERS K. D., BROUTHERS L. E. (2003), Why service and manufacturing entry mode choices differ: the influence of transaction cost factors, risk and trust, Journal of 
The Impact of the Institutional Framework Quality on the Ownership Strategy. Evidence from EU Foreign Direct Investments in South and Central Eastern Europe

restructuring: entry, exit, and economic performance during 1981-89, Strategic Management Journal 17 (8), 587-611.

CHAO M. C.-H., KUMAR V. (2010), The impacts of institutional distance on the international diversity- performance relationship, Journal of World Business 45 (1), 93-103.

CHEN H., HU M. Y. (2002), An analysis of determinants of entry mode and its impact on performance, International Business Review 11 (2), 193-210.

CHEN S.-F. S., HENNART J.-F. (2002), Japanese investors' choice of joint ventures versus wholly-owned subsidiaries in the US: the role of market barriers and firm capabilities, Journal of International Business Studies 33 (1), 1-18.

CHIAO Y.-C., LO F.-Y., YU C.-M. (2010), Choosing between wholly-owned subsidiaries and joint ventures of MNCs from an emerging market, International Marketing Review 27 (3), 338-365.

CHILD J., TSAI T. (2005), The dynamic between firms' environmental strategies and institutional constraints in emerging economies: evidence from China and Taiwan, Journal of Management Studies 42 (1), 95-125.

CHO K. R., PADMANABHAN P. (2005), Revisiting the role of cultural distance in MNC's foreign ownership mode choice: the moderating effect of experience attributes, International Business Review 14 (3), 307-324.

CHOROMIDES C. (2015), An analysis of the economic determinants and the quality of the institutional framework as factors to attract foreign direct investment in Southeastern Europe: the case of Greece, Journal of Urban and Regional Analysis 7 (1), 35-58.

CHOROMIDES C. (2017), Analysis of the investment activity in South and Central Eastern Europe. A comparative analysis of the corporate growth model, Journal of Urban and Regional Analysis 9 (1), 5-32.

CHUNG C. C., BEAMISH P. W. (2005), The impact of institutional reforms on characteristics and survival of foreign subsidiaries in emerging economies, Journal of Management Studies 42 (1), 35-62.

CLARKE J. E., TAMASCHKE R., LIESCH P. W. (2013), International experience in international business research: a conceptualization and exploration of key themes, International Journal of Management Reviews 15 (3), 265-279.

CLAVER E., QUER D. (2005), Choice of market entry mode in China: the influence of firm specific factors, Journal of General Management 30 (3), 51-70.

CONTRACTOR F. J., LORANGE P. (1988), Competition vs. cooperation: a benefit/cost framework for choosing between fully-owned investments and cooperative relationships, Management International Review Special Issue, 5-18.

CONTRACTOR F. J., KUNDU S. K. (1998), Modal choice in a world of alliances: analysing organizational forms in the international hotel sector, Journal of International Business Studies 29 (2), 325-356.

CUERVO-CAZURRA A. (2006), Who cares about corruption?, Journal of International Business Studies 37 (6), 807-822.

CUERVO-CAZURRA A. (2008), The effectiveness of laws against bribery abroad, Journal of International Business Studies 39 (4), 634-651.

CUI L., JIANG F. (2009), FDI entry mode choice of Chinese firms: A strategic behavior perspective, Journal of World Business 44 (4), 434-444.

CUI L., MEYER K. E., WEI HU H. (2014), What drives firms' intent to seek strategic assets by foreign direct investment? A study of emerging economy firms, Journal of World Business 49, 488-501.

DAHLSTRÖM T., JOHNSON A. (2007), Bureaucratic corruption, MNEs and FDI, MIMEO, CESIS / KTH, Stockholm.

DAS T. K., TENG B.-S. (2000), A resource-based theory of strategic alliances, Journal of Management 26 (1), 31-61.

DAUDE C., STEIN E. (2007), The Quality of Institutions and Foreign Direct Investment, Economics \& Politics 19 (3), 317-344. 
Management Studies 40 (5), 1179-1204.

BROUTHERS K. D., BROUTHERS L. E., WERNER S. (2003), Transaction costenhanced entry mode choices and firm performance, Strategic Management Journal 24 (12), 1239-1248.

BROUTHERS K. D., BROUTHERS L. E., WERNER S. (2008a), Real options, international entry mode choice and performance, Journal of Management Studies 45 (5), 936 960.

BROUTHERS K. D., BROUTHERS L. E., WERNER S. (2008b), Resource-based advantages in an international context, Journal of Management 34 (2), 189-217.

BROUTHERS K. D., HENNART J.-F. (2007), Boundaries of the firm: insights from international entry mode research, Journal of Management 33 (3), 395-425.

BRUNETTI A., KISUNKO G., WEDER B. (1997), Institutions in transition: reliability of rules and economic performance in former socialist countries, World Bank, Washington, DC.

BUCHANAN B., ENGLISH II P. C. (2007), Law, finance, and emerging market returns, Emerging Markets Review 8 (3), 181-193.

BUCHANAN B. G., LE Q. V., RISHI M. (2012), Foreign direct investment and institutional quality: Some empirical evidence, International Review of Financial Analysis 21, 81 -89 .

BUCKLEY P. J., CASSON M. (1996), An economic model of international joint venture strategy, Journal of International Business Studies 27 (5), 849-876.

BUCKLEY P. J., CASSON M. C. (1998), Analyzing foreign market entry strategies: extending the internalization approach, Journal of International Business Studies 29 (3), 539561.

BUCKLEY P. J., PASS C. L., PRESCOTT K. (1992), The internalization of service firms: a comparison with the manufacturing sector, Scandinavian International Business Review 1 (1), 39-56.

BUSSE M., GROIZARD J. L. (2008), Foreign direct investment, regulations and growth, The World Economy 31 (7), 861-886.

BUSSE M., HEFEKER C. (2007), Political risk, institutions and foreign direct investment, European Journal of Political Economy 23 (2), 397-415.

BUSSMANN M. (2010), Foreign direct investment and militarized international conflict, Journal of Peace Research 47 (2), 143-153.

BUTKIEWICZ J. L., YANIKKAYA H. (2006), Institutional quality and economic growth: maintenance of the rule of law or democratic institutions, or both?, Economic Modelling 23 (4), 648-661.

CAMPOS J. E., LIEN D., PRADHAN S. (1999), The impact of corruption on investment: predictability matters, World Development 27 (6), 1059-1067.

CANABAL A., WHITE G. O. (2008), Entry mode research: past and future, International Business Review 17 (3), 267-284.

CAPRON L., MITCHELL W., SWAMINATHAN A. (2001), Asset divestiture following horizontal acquisitions: a dynamic view, Strategic Management Journal 22 (9), 817-844.

CAVES R. E. (1996), Multinational Enterprise and Economic analysis, Cambridge University Press, Cambridge.

CAVES R., MEHRA S. (1986), Entry of foreign multinationals into U.S. manufacturing industries, in: Porter M. E. (ed.), Competition in Global Industries, Harvard Business School Press, Boston, pp. 449-482.

CHADEE D., KOUZNETSOV A., ROXAS B. (2014), Institutional Reform and Export Competitiveness of Central and Eastern European Economies, in: Zhuplev A., Liuhto K. (eds.), Geo-Regional Competitiveness in Central and Eastern Europe, the Baltic Countries, and Russia, IGI Global, Hershey, pp. 1-31.

CHANG S. J. (1995), International expansion strategy of Japanese firms: capability building through sequential entry, The Academy of Management Journal 38 (2), 383-407.

CHANG S. J. (1996), An evolutionary perspective on diversification and corporate 
DAUTI B. (2015), Determinants of foreign direct investment in south east European countries and new member states of European Union countries, Economic and Business Review 17 (1), 93-115.

DAVIDSON W. H. (1982), Global Strategic Management, John Wiley and Sons, New York.

DELIOS A., HENISZ W. J. (2003), Political hazards, experience, and sequential entry strategies: the international expansion of Japanese firms, 1980-1998, Strategic Management Journal 24 (11), 1153-1164.

DEMIRBAG M., TATOGLU E., GLAISTER K. W. (2007), Factors influencing perceptions of performance: The case of western FDI in an emerging market, International Business Review 16 (3), 310-336.

DEMIRBAG M., TATOGLU E., GLAISTER K. W. (2010), Institutional and transaction cost influences on partnership structure of foreign affiliates, Management International Review 50 (6), 709-745.

DENG P. (2009), Why do Chinese firms tend to acquire strategic assets in international expansion?, Journal of World Business 44 (1), 74-84.

DIERICKX I., COOL K. (1989), Asset stock accumulation and sustainability of competitive advantage, Management Science 35 (12), 1504-1511.

DIKOVA D., VAN WITTELOOSTUIJN A. (2007), Foreign direct investment mode choice: entry and establishment modes in transition economies, Journal of International Business Studies 38 (6), 1013-1033.

DRABEK Z., PAYNE W. (2002), The impact of transparency on foreign direct investment, Journal of Economic Integration 17 (4), 777-810.

DUMLUDAG D. (2009), An analysis of the determinants of foreign direct investment in Turkey: The role of the institutional context, Journal of Business Economics and Management $10(1), 15-30$.

DUNNING J. H. (1995), What's wrong-and right-with trade theory, The International Trade Journal 9 (2), 163-202.

DUNNING J. H. (2004), Determinants of foreign direct investment: Globalizationinduced changes and the role of policies, Annual World Bank Conference on Development Economics, Europe 2003: Toward pro-poor policies-aid, institutions, and globalization, Oslo, pp. 279-290.

DUNNING J. H. (2006), Comment on Dragon multinationals: new players in 21st century globalization, Asian Pacific Journal of Management 23 (2), 139-141.

DUNNING J. H., LUNDAN S. M. (2008), Multinational enterprises and the global economy, Edward Elgar Publishing, Cheltenham.

DUTTA N., ROY S. (2009), What Attracts Foreign Direct Investment: A closer look, Economic Affairs 29 (3), 81-86.

EDEN L., MILLER S. R. (2004), Distance Matters: Liability of Foreignness, Institutional Distance and Ownership Strategy, in: Hitt M. A., Cheng J. L. C. (eds.), Theories of the Multinational Enterprise: Diversity, Complexity and Relevance (Advances in International Management, vol. 16), Emerald Group Publishing Limited, New York, pp. 187-221.

EDISON H. (2003), Testing the links. How strong are the links between institutional quality and economic performance?, Finance \& Development 40 (2), 35-37.

EGGER P., WINNER H. (2005), Evidence on corruption as an incentive for foreign direct investment, European Journal of Political Economy 21 (4), 932-952.

ERRAMILLI M. K. (1991), The experience factor in foreign market entry behavior of service firms, Journal of International Business Studies 22 (3), 479-501.

ERRAMILLI M. K., RAO C. P. (1993), Service firms' international entry-mode choice: a modified transaction-cost analysis approach, Journal of Marketing 57 (3), 19-38.

ELLIS P. D. (2008), Does psychic distance moderate the market size-entry sequence relationship?, Journal of International Business Studies 39 (3), 351-369.

ESTRIN S. (2002), Competition and corporate governance in transition, Journal of 
The Impact of the Institutional Framework Quality on the Ownership Strategy. Evidence from EU Foreign Direct Investments in South and Central Eastern Europe

Economic Perspectives 16 (1), 101-124.

ESTRIN S., MEYER K. E., WRIGHT M., FOLIANO F. (2008), Export propensity and intensity of subsidiaries in emerging economies, International Business Review 17 (5), 574586.

ESTRIN S., BAGHDASARYAN D., MEYER K. E. (2009), The impact of institutional and human resource distance on international entry strategies, Journal of Management Studies 46 (7), 1171-1196.

ESTRIN S., UVALIC M. (2014), Foreign direct investment into transition economies: are the Balkans different?, Economics of Transition 22 (2), 281-312.

EVANS J., MAVONDO F. T., BRIDSON K. (2008), Psychic distance: Antecedents, retail strategy implications, and performance outcomes, Journal of International Marketing 16 (2), 3263.

FAETH I. (2009), Determinants of foreign direct investment - a tale of nine theoretical models, Journal of Economic Surveys 23 (1), 165-196.

FAROLE T., WINKLER D. (2012), Foreign firm characteristics, absorptive capacity and the institutional framework: the role of mediating factors for FDI spillovers in low- and middleincome countries, World Bank Washington, DC.

FILIPPAIOS F., KOTTARIDI C. (2013), Complements or substitutes? New theoretical considerations and empirical evidence on the imports and FDI relationship in Central and Eastern European Countries, International Review of Applied Economics 27 (6), 766-797.

FUNG K. C., IIZAKA H., PARKER S. (2002), Determinants of U.S. and Japanese Direct Investment in China, Journal of Comparative Economics 30 (3), 567-578.

GAO S. (1996), China's Economic Reform, Palgrave Macmillan, UK.

GANI A. (2007), Governance and foreign direct investment links: evidence from panel data estimations, Applied Economics Letters 14 (10), 753-756.

GASTANAGA V. M., NUGENT J. B., PASHAMOVA B. (1998), Host country reforms and FDI inflows: How much difference do they make?, World Development 26 (7), 1299-1314.

GATIGNON H., ANDERSON E. (1988), The multinational corporation's degree of control over foreign subsidiaries: an empirical test of a transaction cost explanation, Journal of Law, Economics and Organization 4 (2), 305-336.

GAUR A. S., LU J. W. (2007), Ownership strategies and survival of foreign subsidiaries: impacts of institutional distance and experience, Journal of Management 33 (1), 84-110.

GELBUDA M., MEYER K. E., DELIOS A. (2008), International business and institutional development in Central and Eastern Europe, Journal of International Management 14 (1), 1-11. GETZ K. A., VOLKEMA R. J. (2001), Culture, perceived corruption and economics: a model of predictors and Outcomes, Business \& Society 40 (1), 7-30.

GLIGOROV V. (2000) (ed.), Balkan Reconstruction: Economic Aspects, The Vienna Institute of International Economic Studies, Vienna.

GOMES-CASSERES B. (1989), Ownership structures of foreign subsidiaries: theory and evidence, Journal of Economic Behavior \& Organization 11 (1), 1-25.

GOMES-CASSERES B. (1990), Firm ownership preferences and host government restrictions: an integrated approach, Journal of International Business Studies 21 (1), 1-22.

GLOBERMAN S., SHAPIRO D. (2002), Global foreign direct investment flows: The role of governance infrastructure, World Development 30 (11), 1899-1919.

GLOBERMAN S., SHAPIRO D. (2003), Governance infrastructure and US foreign direct investment, Journal of International Business Studies 34 (1), 19-39.

GLOBERMAN S., SHAPIRO D., TANG Y. (2006), Foreign Direct Investment in emerging and transition European countries, International Finance Review 6, 431-459.

GREENE W. H. (1997), Econometric Analysis, Prentice-Hall, Upper Saddle River.

GREENWOOD R., HININGS C. R. (1996), Understanding radical organizational change: Bringing together the old and the new institutionalism, The Academy of Management Review 21 (4), 1022-1054.

GREWAL R., DHARWADKAR R. (2002), The role of the institutional environment in 
marketing channels, Journal of Marketing 66 (3), 82-97.

GROH A. P., WICH M. (2009), A composite measure to determine a host country's attractiveness for foreign direct investment, IESE Business School Working Paper No 833, Barcelona.

GULER I., GUILLEN M. F., MACPHERSON J. (2002), Global competition, institutions and the diffusion of organizational practices: the international spread of ISO 9000 quality certificates, Administrative Science Quarterly 47 (2), 207-232.

GWARTNEY J., LAWSON R., NORTON S. (2008), Economic Freedom of the World: 2008 Annual Report, Economic Freedom Network, Vancouver, BC.

HABIB M., ZURAWICKI L. (2002), Corruption and foreign direct investment, Journal of International Business Studies 33 (2), 291-307.

HAAR L. N., MARINESCU N. (2014), Entry Modes and Firm Performance in a Transition Economy: Evidence from Inward FDI to Romania, Journal of East-West Business 20 (1), 44-67.

HELFAT C. E., PETERAF M. A. (2003), The dynamic resource-based view: capability lifecycles, Strategic Management Journal 24 (10), 997-1010.

HENISZ W. J. (1998), The institutional environment for international investment: Safeguarding against state sector opportunism and opportunistic use of the state, University of California, Berkeley. HENISZ W. J. (2000a), The institutional environment for economic growth, Economics and Politics 12 (1), 1-31. HENISZ W. J. (2000b), The institutional environment for multinational investment, The Journal of Law, Economics and Organization 16 (2), 334-364. HENISZ W. J. (2003), The power of Buckley and Casson thesis: the ability to manage institutional idiosyncrasies, Journal of International Business Studies 34 (2), 173-184. HENISZ W. J. (2005), The Institutional Environment for International Business, in: Beckley P. J. (ed.), What is International Business, Palgrave Macmillan, New York. HENISZ W. J., WILLIAMSON O. E. (1999), Comparative economic organization - within and between countries, Business and Politics 1 (3), 261-277. HENNART J. F. (1988), Upstream vertical integration in the aluminium and tin industries: A comparative study of the choice between market and intrafirm coordination, Journal of Economic Behavior \& Organization 9 (3), 281-299.

HENNART J.-F. (1991), The transaction costs theory of joint ventures: an empirical study of Japanese subsidiaries in the United States, Management Science 37 (4), 483-497. HENNART J.-F., LARIMO J. (1998), The impact of culture on the strategy of multinational enterprises: Does national origin affect ownership decisions?, Journal of International Business Studies 29 (3), 515-538.

HERMANN P., DATTA D. K. (2002), CEO successor characteristics and the choice of foreign market entry mode: an empirical study, Journal of International Business Studies 33 (3), 551-569.

HERITAGE FOUNDATION (2017a), Index of Economic Freedom 2017: Country

Reports, Retrieved from: www.heritage.org. HERITAGE FOUNDATION (2017b), About the Index, Retrieved from: www.heritage.org.

HILL C. W. L., HWANG P., KIM W. C. (1990), An eclectic theory of the choice of international entry mode, Strategic Management Journal 11 (2), 117-128. HOSKISSON R. E., EDEN L., LAU C. M., WRIGHT M. (2000), Strategy in emerging economies, Academy of Management Journal 43 (3), 249-267. HUNYA G. (2000), Recent FDI trends, policies and challenges in South-East European Countries, WIIW, Vienna. IAMMARINO S., PITELIS C. (2000), Foreign direct investment and 'less favoured regions': Greek FDI in Bulgaria and Romania, Global Business Review 1 (2),155-171. JENSEN N. M. (2003), Democratic governance and multinational corporations: political 
regimes and inflows of foreign direct investment, International Organization 57 (3), 587-616. JIMENEZ A. (2010), Does political risk affect the scope of the expansion abroad? Evidence from Spanish MNEs, International Business Review 19 (6), 619-633. JUDE C., LEVIEUGE G. (2017), Growth Effect of Foreign Direct Investment in Developing Economies: The Role of Institutional Quality, The World Economy 40 (4), 715-742. KADITI E. A. (2013), Foreign investments and institutional convergence in Southeastern Europe, International Economic Journal 27 (1), 109-126.

KAMAL S. (2009), Greenfield vs acquisitions: determinants of choice in emerging economies, BRAC University Journal 6 (2), 63-71.

KAPURIA-FOREMAN V. (2007), Economic freedom and foreign direct investment in developing countries, The Journal of Developing Areas 41 (1), 143-154.

KAUFMANN D., KRAAY A., MASTRUZZI M. (2005), Governance matters IV: governance indicators for 1996-2004, World Bank, Washington, DC.

KAYNAK E., DEMIRBAG M., TATOGLU E. (2007), Determinants of ownership-based entry mode choice of MNEs: evidence from Mongolia, Management International Review 47 (4), 505-530.

KEDIA B. L., MUKHERJEE D., LAHIRI S. (2006), Indian business groups: evolution and transformation, Asia Pacific Journal of Management 23 (4), 559-577.

KHAN M. M., AKBAR M. I. (2013), The impact of political risk on foreign direct investment, International Journal of Economics and Finance 5 (8), 147-156.

KHANNA T., PALEPU K. G., SINHA J. (2005), Strategies that fit emerging markets, Harvard Business Review 83 (6), 63-74.

KHANNA T., PALEPU K. G. (2010), Winning in emerging markets: a roadmap for strategy and execution, Harvard University Press, Cambridge, MA.

KIM W. C., HWANG P. (1992), Global strategy and multinationals' entry mode choice, Journal of International Business Studies 23 (1), 29-53.

KLEIN S., FRAZIER G. L., ROTH V. J. (1990), A transaction cost analysis model of channel integration in international markets, Journal of Marketing Research 27 (2), 196-208.

KOGUT B., SPICER A. (2002), Capital market development and mass privatization are logical contradictions: lessons from Russia and the Czech Republic, Industrial and Corporate Change 11 (1), 1-37.

KOGUT B., ZANDER U. (1995), Knowledge, Market Failure and the multinational enterprise: A Reply, Journal of International Business Studies 26 (2), 417-426.

KOSTOVA T., ROTH K. (2002), Adoption of an organizational practice by subsidiaries of multinational corporations: institutional and relational effects, The Academy of Management Journal 45 (1), 215-233.

KSHETRI N. (2010), Business perceptions of regulative institutions in Central and Eastern Europe, Baltic Journal of Management 5 (3), 356-377.

LA PORTA R., LOPEZ-DE-SILANES F., SHLEIFER A., VISHNY R. W. (1997), Legal determinants of external finance, The Journal of Finance 52 (3), 1131-1150.

LA PORTA R., LOPEZ-DE-SILANES F., SHLEIFER A., VISHNY R. (1999), The quality of government, Journal of Law, Economics and Organization 15 (1), 222-279.

LARIMO J. (1993), Foreign direct investment behaviour and performance: an analysis of Finnish direct manufacturing investments in OECD countries, University of Vaasa, Vaasa. LARIMO J. A., NGUYEN H. L. (2015), International joint venture strategies and performance in the Baltic States, Baltic Journal of Management 10 (1), 52-72.

LEE Y.-H. (2010), A resource-based perspective of entry mode choices of electronic components industry into China, Proceedings of the International Conference on Future Information Technology and Management Engineering, 540-545.

LI P.-Y., MEYER K. E. (2009), Contextualizing experience effects in international business: A study of ownership strategies, Journal of World Business 44 (4), 370-382.

LI J. (1994), Experience effects and international expansion: strategies of service MNCs in the Asia-Pacific region, Management International Review 34 (3), 217-234. 
LI J., YANG J. Y., YUE D. R. (2007), Identity, community, and audience: how wholly owned foreign subsidiaries gain legitimacy in China, Academy of Management Journal 50 (1), 175-190.

LIM E.-G. (2001), Determinants of, and the relation between, foreign direct investment and growth: a summary of the recent literature, International Monetary Fund, Washington, DC.

LIN Z., PENG M. W., YANG H., SUN S. L. (2009), How do networks and learning drive M\&As? An institutional comparison between China and the United States, Strategic Management Journal 30, 1113-1132.

MAKINO S., NEUPERT K. E. (2000), National culture, transaction costs, and the choice between joint venture and wholly owned subsidiary, Journal of International Business Studies 31 (4), 705-713.

(3), 681-712

MAURO P. (1995), Corruption and Growth, The Quarterly Journal of Economics 110

MCCLOUD N., KUMBHAKAR S. C. (2012), Institutions, foreign direct investment and growth: a hierarchical Bayesian approach, Royal Statistical Society 175 (1), 83-105.

MEYER K. (2001a), International business research in transition economies, in: Rugman A., Brewer T. (eds.), Oxford Handbook on International Business, Oxford University Press, Oxford.

MEYER K. E. (2001b), Institutions, transaction costs, and entry mode choice in Eastern Europe, Journal of International Business Studies 32 (2), 357-367.

MEYER K. E. (2002), Management challenges in privatization acquisitions in transition economies, Journal of World Business 37 (4), 266-276.

MEYER K. E., ESTRIN S. (2001), Brownfield entry in emerging markets, Journal of International Business Studies 32 (3), 575-584.

MEYER K. E., ESTRIN S., BHAUMIK S. K., PENG M. W. (2009a), Institutions, resources, and entry strategies in emerging economies, Strategic Management Journal 30 (1), 61-80.

MEYER K. E., PENG M. W. (2005), Probing theoretically into Central and Eastern Europe: transactions, resources, and institutions, Journal of International Business Studies 36 (6), 600-621.

MEYER K. E., TRAN Y. T. T. (2006), Market penetration and acquisition strategies for emerging economies, Long Range Planning 39 (2), 177-197.

MEYER K. E., WRIGHT M., PRUTHI S. (2009b), Managing knowledge in foreign entry strategies: a resource-based analysis, Strategic Management Journal 30 (5), 557-574.

MINTZBERG H., QUINN J. (1992), The Strategy Process: Concepts and Contexts, Prentice Hall, Englewood Cliffs.

MORSCHETT D., SCHRAMM-KLEIN H., SWOBODA B. (2010), Decades of research on market entry modes: What do we really know about external antecedents of entry mode choice?, Journal of International Management 16 (1), 60-77.

MONTEVERDE K., TEECE D. J. (1982), Supplier switching costs and vertical integration in the automobile industry, The Bell Journal of Economics 13 (1), 206-213.

NAUDÉ W. A., KRUGELL W. F. (2007), Investigating geography and institutions as determinants of foreign direct investment in Africa using panel data, Applied Economics 39 (10), 1223-1233.

NELSON R., WINTER S. (1982), The Evolutionary Theory of the Firm, The Belknap Press of Harvard University Press, Cambridge.

NITSCH D., BEAMISH P., MAKINO S. (1996), Entry Mode and Performance of Japanese FDI in Western Europe, MIR: Management International Review 36 (1), 27-43.

NOORBAKHSH F., PALONI A., YOUSSEF A. (2001), Human capital and FDI inflows to developing countries: New empirical evidence, World Development 29 (9), 1593-1610.

NORTH D. C. (1981), Structure and change in economic history, Norton, New York.

NORTH D. C. (1990), Institutions, Institutional Change and Economic Performance, Cambridge University Press, New York. 
NORTH D. C. (1991), Institutions, Journal of Economic Perspectives 5 (1), 97-112.

NORTH D. C. (2005), Understanding the process of economic change, Princeton University Press, New Jersey.

PADMANABHAN P., CHO K. R. (1996), Ownership strategy for a foreign affiliate: an empirical investigation of Japanese firms, MIR: Management International Review 36 (1), $45-$ 65.

PANTELIDIS P., NIKOLOPOULOS E. (2008), FDI attractiveness in Greece, International Advances in Economic Research 14 (1), 90-100.

PAUL D. L., WOOSTER R. B. (2008), Strategic investments by US firms in transition economies, Journal of International Business Studies 39 (2), 249-266.

PENG M. W. (2003), Institutional transitions and strategic choices, Academy of Management Review 28 (2), 275-296.

PENG M. W. (2006), Making M\&A fly in China, Harvard Business Review 84 (3), 26-27. Ohio.

PENG M. W. (2008), Global Business, South-Western College Publishing, Cincinnati,

PENG M. W., HEATH P. (1996), The growth of the firm in planned economies in transition: institutions, organizations, and strategic choice, The Academy of Management Review 21 (2), 492-528.

PENG M. W., KHOURY T. A. (2009), Unbundling the institution-based view of international business strategy, in: Rugman A. M. (ed.), The Oxford Handbook of International Business, Oxford University Press, New York, pp. 256-268.

PETRAKOS G., TOTEV S. (eds.) (2001), The Development of the Balkan Region, Ashgate, Aldershot.

PORTER M., FULLER M. B. (1986), Coalitions and Global Strategy, in: Porter M. E. (ed.), Competition in Global Industries, Harvard Business School Press, Boston, pp. 315-344.

POURNARAKIS M., VARSAKELIS N. C. (2004), Institutions, internationalization and FDI: the case of economies in transition, Transnational Corporations 13 (2), 77-94.

GORYNIA M., NOWAK J., TRAPCZYNSKI P., WOLNIAK R. (2015), Establishment Mode Choices of Emerging Multinationals: Evidence from Poland, Managing Global Transitions $13(2), 101-124$.

RA W., ABUOVA A. (2017), Determinants of equity-based entry mode choices of foreign investors in Kazakhstan, International Journal of Management and Applied Science 3 (10), 11-17.

RAMCHARRAN H. (2000), Foreign direct investments in Central and Eastern Europe: an analysis of regulatory and country risk factors, Latin American Business Review 18 (2), 1-8.

RESMINI L. (2000), The Determinants of Foreign Direct Investment in the CEECs: New evidence from sectoral patterns, Economics of Transition 8 (3), 665-689.

RICHARDS D. C., NWANKWO S. (2005), Reforming the legal environment of business in Sub-Saharan Africa: Moderating effects on foreign direct investment, Managerial Law 47 (5), 154-163.

RODRIK D. (2004), Globalization and growth - Looking in the wrong places, Journal of Policy Modeling 26 (4), 513-517.

RODRIK D., SUBRAMANIAN A., TREBBI F. (2004), Institutions rule: The primacy of institutions over geography and integration in economic development, Journal of Economic Growth 9 (2), 131-165. MA.

ROOT F. R. (1987), Entry Strategies for International Markets, D. C. Heath, Lexington,

SCOTT W. R. (2008), Institutions and Organizations: Ideas and Interests, Sage, Thousand Oaks, CA.

SELS A. T. H. (2006), Foreign direct investment as an entry mode. An application in emerging economies, Tilburg University, Tilburg.

SHENKAR O. (2001), Cultural distance revisited: towards a more rigorous conceptualization and measurement of cultural differences, Journal of International Business 
Studies 32 (3), 519-535.

SHLEIFER A., VISHNY R. W. (1993), Corruption, The Quarterly Journal of Economics $108(3), 599-617$.

SIMON J. L. (1969), Basic Research Methods in Social Science, Random House, New York.

SINGH H., JUN K. W. (1995), Some new evidence on determinants of foreign direct investment in developing countries, World Bank, Washington, DC.

SLANGEN A. H. L., HENNART J.-F. (2008), Do multinationals really prefer to enter culturally distant countries through greenfields than through acquisitions? The role of parent experience and subsidiary autonomy, Journal of International Business Studies 39 (3), $472-$ 490.

STAATS J. L., BIGLAISER G. (2012), Foreign direct investment in Latin America: The importance of

judicial strength and rule of law, International Studies Quarterly 56 (1), 193-202.

STEENSMA H. K., TIHANYI L., LYLES M. A., DHANARAJ C. (2005), The evolving value of foreign partnerships in transitioning economies, Academy of Management Journal 48 (2), 213-235.

STEIN E., DAUDE C. (2001), Institutions, integration and the location of foreign direct investment, OECD Global Forum on International Investment, Mexico City.

STEPHEN K., PHILIP K. (1995), Institutions and economic performance: cross-country tests using alternative institutional measures, Economics and Politics 7 (3), 207-227.

STERN N. (2003), Investment climate: lessons and challenges, The Egyptian Center for Economic Studies, Cairo.

DC.

STIGLITZ J. (1999), Whither reform? Ten years of transition, World Bank, Washington,

SVEJNAR J. (2002), Transition economies: Performance and challenges, The Journal of Economic Perspectives 16 (1), 3-28.

TALLMAN S., FLADMOE-LINDQUIST K. (2002), Internationalization, globalization, and capability-based strategy, California Management Review 45 (1), 116-135.

TANG R., DEVINNEY T. (2015), The Effects of Experience on Choosing an International Entry Mode, The Academy of International Business (AIB) Annual Conference, 137.

TAYLOR C. R., ZOU S., OSLAND G. E. (1998), A transaction cost perspective on foreign market entry strategies of US and Japanese firms, Thunderbird International Business Review 40 (4), 389-412.

TEECE D. J. (1986), Transaction cost economics and the multinational enterprise. An Assessment, Journal of Economic Behavior \& Organization 7 (1), 21-45.

TIHANYI L., GRIFFITH D. A., RUSSELL C. J. (2005), The effect of cultural distance on entry mode choice, international diversification, and MNE performance: a meta-analysis, Journal of International Business Studies 36 (3), 270-283.

TREVINO L. J., THOMAS D. E., CULLEN J. (2008), The three pillars of institutional theory and FDI in Latin America: An institutionalization process, International Business Review $17(1), 118-133$

TONG T. W., REUER J. J., PENG M. W. (2008), International joint ventures and the value of growth options, The Academy of Management Journal 51 (5), 1014-1029.

UHLENBRUCK K., DE CASTRO J. O. (2000), Foreign acquisitions in Central and Eastern Europe: outcomes of privatization in transitional economies, The Academy of Management Journal 43 (3), 381-402.

VERNON R. (1983), Organisational and Institutional Responses to International Risk, in: Herring R. J. (ed.), Managing International Risk, Cambridge University Press, Cambridge, MA.

VIJAYAKUMAR N., SRIDHARAN P., RAO K. C. S. (2010), Determinants of FDI in BRICS countries: a panel analysis, International Journal of Business Science and Applied 
The Impact of the Institutional Framework Quality on the Ownership Strategy. Evidence from EU Foreign Direct Investments in South and Central Eastern Europe

Management 5 (3), 1-13

WACH K., WOJCIECHOWSKI L. (2016), Determinants of inward FDI into Visegrad countries: empirical evidence based on panel data for the years 2000-2012, Economics and Business Review 2 (1), 34-52.

WALKENHORST P. (2004), Economic transition and the sectoral patterns of foreign direct investment, Emerging Markets Finance \& Trade 40 (2), 5-26.

WAN W. P., HOSKISSON R. E. (2003), Home country environments, corporate diversification strategies, and firm performance, The Academy of Management Journal 46 (1), 27-45.

WEI S.-J. (2000), How taxing is corruption on international investors?, The Review of Economics and Statistics $82(1), 1-11$

WEI S.-J., SHLEIFER A. (2000), Local corruption and global capital flows, Brookings Papers on Economic Activity 2000 (2), 303-354.

WEI Y., LIU B., LIU X. (2005), Entry modes of foreign direct investment in China: a multinomial logit approach, Journal of Business Research 58 (11), 1495-1505.

WHEELER D., MODY A. (1992), International investment location decisions: The case of U.S. firms, Journal of International Economics 33 (1-2), 57-76.

WILLIAMSON O. E. (1981), The economics of organization: the transaction cost approach, American Journal of Sociology 87 (3), 548-577.

WILLIAMSON O. E. (1985), The economic institutions of capitalism. Firms, markets, relational contracting, The Free Press, New York.

WILLIAMSON O. E. (2000), The new institutional economics: taking stock, looking ahead, Journal of Economic Literature 38 (3), 595-613.

WOODCOCK C. P., BEAMISH P. W., MAKINO S. (1994), Ownership-Based Entry Mode Strategies and International Performance, Journal of International Business Studies 25 (2), 253-273.

WRIGHT M., FILATOTCHEV I., HOSKISSON R. E., PENG M. W. (2005), Strategy research in emerging economies: challenging the conventional wisdom, Journal of Management Studies 42 (1), 1-33.

XU D., SHENKAR O. (2002), Institutional distance and the multinational enterprise, The Academy of Management Review 27 (4), 608-618.

XU D., PAN Y., BEAMISH P. W. (2004), The effect of regulative and normative distances on MNE ownership and expatriate strategies, MIR: Management International Review 44 (3), 285-307.

YIU D., MAKINO S. (2002), The choice between joint venture and wholly owned subsidiary: an institutional perspective, Organization Science 13 (6), 667-683.

YAMAKAWA Y., PENG M. W, DEEDS D. L. (2008), What drives new ventures to internationalize from emerging to developed economies?, Entrepreneurship Theory and Practice 32 (1), 59-82.

YOUNG M. N., PENG M. W., AHLSTROM D., BRUTON G. D., JIANG Y. (2008), Corporate governance in emerging economies: a review of the principal-principal perspective, Journal of Management Studies 45 (1), 196-220.

YU J., LEE S.-H., HAN K. (2015), FDI motives, market governance, and ownership choice of MNEs: A study of Malaysia and Thailand from an incomplete contracting perspective, Asia Pacific Journal of Management 32 (2), 335-362.

ZAHEER S. (1995), Overcoming the liability of foreignness, The Academy of Management Journal 38 (2), 341-363.

ZEKIRI J. (2016), Motivating factors and the modes of entry in other markets, ECOFORUM 5 Special Isssue, 9-18.

ZHAO H., LUO Y., SUH T. (2004), Transaction cost determinants and ownership-based entry mode choice: a meta-analytical review, Journal of International Business Studies 35 (6), 524-544.

ZWEYNERT J., GOLDSCHMIDT N. (2006), The two transitions in Central and Eastern 


\section{Constantinos CHOROMIDES}

Europe as processes of institutional transplantation, Journal of Economic Issues 40 (4), 895918.

Initial submission: 08.01.2018

Revised submission: 15.05 .2018

Final acceptance: 23.05 .2018

Correspondence: School for Work Based Education, Glasgow Caledonian University, 70 Cowcaddens Road, Glasgow G4 0BA, United Kingdom.

Email: constantinos.choromides@gcu.ac.uk 